\title{
Tectonic evolution of the Sicilian Thrust System (central Mediterranean)
}

\author{
Giuseppe NAPOLI, Fabrizio NIGRO, Pietro RENDA, \\ Andrzej ŚLACZKA and Rocco FAVARA
}

Napoli G., Nigro F., Renda P., Ślączka A. and Favara R. (2012) - Tectonic evolution of the Sicilian Thrust System (central Mediterranean). Geol. Quart., 56 (4): 579-600, doi: 10.7306/gq.1043

\begin{abstract}
The Sicilian Thrust System (STS) is a south-verging (Africa-verging) fold-and-thrust belt including a Mesozoic-Paleogene sedimentary sequence. This thrust stack owes its origin to the deformation of pre-orogenic strata deposited in different palaeogeographic domains belonging to passive margins of the African plate. The STS was deformed during the Neogene, following the closure of the Tethys Ocean and the continental collision between the Sardo-Corso Block and the north Africa margins. The thrust pile was detached from the underlying basement during the Miocene-Pleistocene. The regional-scale structural setting recognized allows us to reconstruct the tectonic evolution of the STS as follows: I - piggy-back thrusting from the Late Oligocene to the Langhian, inducing the building of the Inner Sicilian Chain (ISC); II - piggy-back thrusting from the Langhian to the Tortonian, inducing the formation of the Middle Sicilian Chain (MSC); III - generalized extensional deformation in the chain-foredeep-foreland system from the Tortonian to the Early Pliocene; IV - a new onset of piggy-back thrusting after the Early Pliocene allowed the building of the Outer Sicilian Chain and out-of-sequence thrusting in the previously developed ISC and MSC.
\end{abstract}

Giuseppe Napoli and Pietro Renda, Dipartimento di Scienze della Terra e del Mare, Universitŕ di Palermo, via Archirafi 22, 90123, Palermo, Italy, e-mail: pietro.renda@unipa.it; Fabrizio Nigro, Pietro Renda and Rocco Favara, Istituto Nazionale di Geofisica e Vulcanologia, sez. di Palermo, via Ugo la Malfa 153, 90146, Palermo, Italy; Andrzej Ślaczka, Institute of Geological Sciences, Jagiellonian University, Oleandry 2a, 30-063 Kraków, Poland (received: March 26, 2012; accepted: August 1, 2012; first published online: October 2, 2012).

Key words: Sicily, Africa margin deposits, thrusting, extension, tectonics, accretionary prism.

\section{INTRODUCTION}

During mountain belt evolution there commonly exist close relationships between different types of structures (e.g., thrust faults and normal faults) or between different deformation regimes (shortening vs extension). Many geologists believe that thrust faults are produced by outward propagation from the internal, core parts of a mountain chain (Roure et al., 1990a and references therein). These faults are defined as normal-sequence thrusts (or in-sequence thrusts). Out-of-sequence thrusting involves younger, higher thrusts that formed by breaking an older thrust sheet within a pile of already-formed thrusts.

To understand how thrusts system form, we need to know the sequence of development of thrusting, that is, whether new faults developed towards the foreland or towards the hinterland. The simple foreland-breaking sequence of deformation characterizing the accretion of a sedimentary wedge during the subduction stage can be interrupted either by backward vergent deformation, syn-orogenic extension or backthrusting/thickening near the orogenic backstop (Platt and Vissers, 1989; Willett and Brandon, 2002; Smit et al., 2003). The dynamics of wedge growth may be partly dictated by localized extensional forces which may support basin formation both in the back of the wedge (piggy-back basins) and in its toe region (foredeep-foreland basins; e.g., Oldow et al., 1993; Mantovani et al., 1997).

The evolution of chain-foredeep-foreland systems is characterized by contractional structures coupled with extensional structures, both at the chain-foredeep and at the foredeep-foreland transition zone (Dewey, 1988). As a consequence, the architecture of most foredeep depressions is generally envisioned as controlled by active regional thrusts and coeval subsidiary normal faults in their inner and outer edges. These structures may contribute to the accommodation of flexure in foreland plates induced by the load of advancing thrust sheets 
(Sciscianni et al., 2001). Also, during continental collision, out-of-sequence deformation is widespread across foldand-thrust belts. The thrust systems accommodate substantial horizontal crustal shortening and these systems are composed of shallowly dipping faults. Most thrust systems are dominated by the progressive cutting of fault ramps and fault splays into the footwall block and thus towards the foreland. Thrust faults in a thrust system need not all have the same vergence as the sole fault that underlies the thrust complex. Faults cutting progressively into the hanging wall block, and thus towards the hinterland, are present at least locally and are called out-of-sequence thrusts or back thrusts. A process that results in the common development of back thrusts is called tectonic wedging. In a variety of tectonic settings, faults called back thrusts may develop that have opposite vergence. Out-of-sequence faults are responsible for internal deformation of wedges (Chapple, 1978), and are caused by reactivation of older in-sequence thrusts or by the development of new thrust faults through a deformed thrust sheet (Morley, 1988).

Foreland propagation seen in thrusting does not show continual development. Many factors causes the thrust sheet to stick. In order to overcome the sticking of the sheet an outof-sequence fault is formed (Morley, 1988). Out-of-sequence faults are also found associated with deformation seen in the sedimentary rocks that come from the underlying plate as the thrust sheet spreads towards the foreland (England and McKenzie, 1982).

Oldow et al. (1993), Keller et al. (1994) and Carmignani et al. (1994) indicated that the tensional stress field observed in the inner part of the Apennines co-exists with a compressional stress field in the foreland part of the belt. This dynamic aspect means that extensional structures are kinematically linked with compressional structures and may represent the evolution in time of the collision processes. The same concept was assumed by Giunta et al. (2000, 2002) for Sicily and by Tricart et al. (1994) for northern Tunisia.

In Sicily we still lack a kinematic model relative to mountain chain building, including the development of in-sequence and out-of-sequence thrusting and also folding and the development of extensional structures (e.g., normal faults). The aim of this paper is to provide constraints to help unravel the structural evolution of the Sicily chain using stratigraphic data and geometric relationships between different map-scale types of structures.

\section{MAIN GEOLOGICAL OUTLINES}

The tectonic setting of the central Mediterranean is dominated by subduction in the Calabrian Arc and by collision between the African and Arabian plates with Eurasia (McKenzie, 1970; Jackson and McKenzie, 1988). The central Mediterranean region exhibits various tectonic phenomena, from continental collision to escape tectonics with major continental strike-slip faults, subduction of continental and oceanic lithosphere and associated back-arc spreading. The combination of convergence and extension has been an enigmatic feature of this region.
The tectonic regime along the plate boundary in north Africa and in a large part of Sicily reflects the convergence between Africa and Eurasia and shows a dominantly NW compressive trend. However, in the Calabrian Arc the stress regime is complex, and diffuse in orientation and depth as well as in the style of deformation. According to Rebai et al. (1992), the stress regime is close to radial extension. In the southern Apennines normal and strike-slip faulting prevail, with extension perpendicular to the trend of the chain (Frepoli and Amato, 2000).

The Sicilian-Maghrebides belt represents the emergent segment of the central Mediterranean Suture Zone, extending from the Sardinia Channel to the Sicily Strait. On land, a southwards-verging accretionary wedge crops out. Inside it, different deformed successions crop out, derived from the Meso-Cenozoic carbonate platforms and intervening pelagic basins. The Calabrian accretionary wedge is a partially submerged accretionary complex located in the Ionian offshore region and laterally bounded by the Apulia and Malta escarpments. The Sicilian-Maghrebides belt has its axial culmination in western Sicily and axial depression in NE Sicily; this trend results from the increasing rotation in oblique convergence (Channell et al., 1980; Nairn et al., 1985; Grasso et al., 1987; Oldow et al., 1990; Nigro and Renda, 2001a). The African lithosphere appears flexed in eastern Sicily by thrust loading and elastic bending of the foreland caused by crustal stacking (Adam, 1996). Jiménez-Munt et al. (2003) concluded that Africa/Arabia versus Eurasia convergence cannot be the only active tectonic mechanism in the Mediterranean. Additional forces, such as slab pull and suction, in the case of the Calabrian Arc, are necessary in order to reproduce the prominent features of the WSM2000 map (Mueller et al., 2000) that contains the information on the stress field in the central Mediterranean area. A common feature of the Alpine orogens in the central Mediterranean region, is in geodynamic evolution during the Cenozoic, is the migration of the subduction trench concomitant with progressive forward propagation of the frontal thrusts in the foreland domain and crustal extension in the back-arc regions (Alvarez et al., 1974; Dewey et al., 1989; Jolivet and Faccenna, 2000). The concomitance of extension and shortening settings has been documented by integrating structural and petrological data coming from high pressure metamorphic units presently exposed in the hinterland regions of the Calabria-Peloritani Arc (Wallis et al., 1993; Rossetti et al., 2004; Heymes et al., 2010).

From the Triassic onwards, Sicily experienced deformation related to the opening of the Tethys Ocean. Coeval normal, strike-slip and oblique-slip faults, developed in the framework of a transtensional regime induced by oblique rifting of the Africa and Europe continental passive margins, affect the Upper Triassic to Late Cretaceous strata of northern Sicily (Catalano and D'Argenio, 1982; Nigro and Renda, 2005). From the Paleogene onwards a reversal in the general relative plate motion induced convergence followed by collision of the European and African margins. The Maghrebides thrust front in Sicily forms an arcuate salient (Fig. 1) where the trend-lines converge at the end points, suggesting basin-controlled bending during Paleogene-Neogene collision.

Variously protruded foreland plate indenters flank this basin, where growth of the orogenic wedge, generated by the ac- 


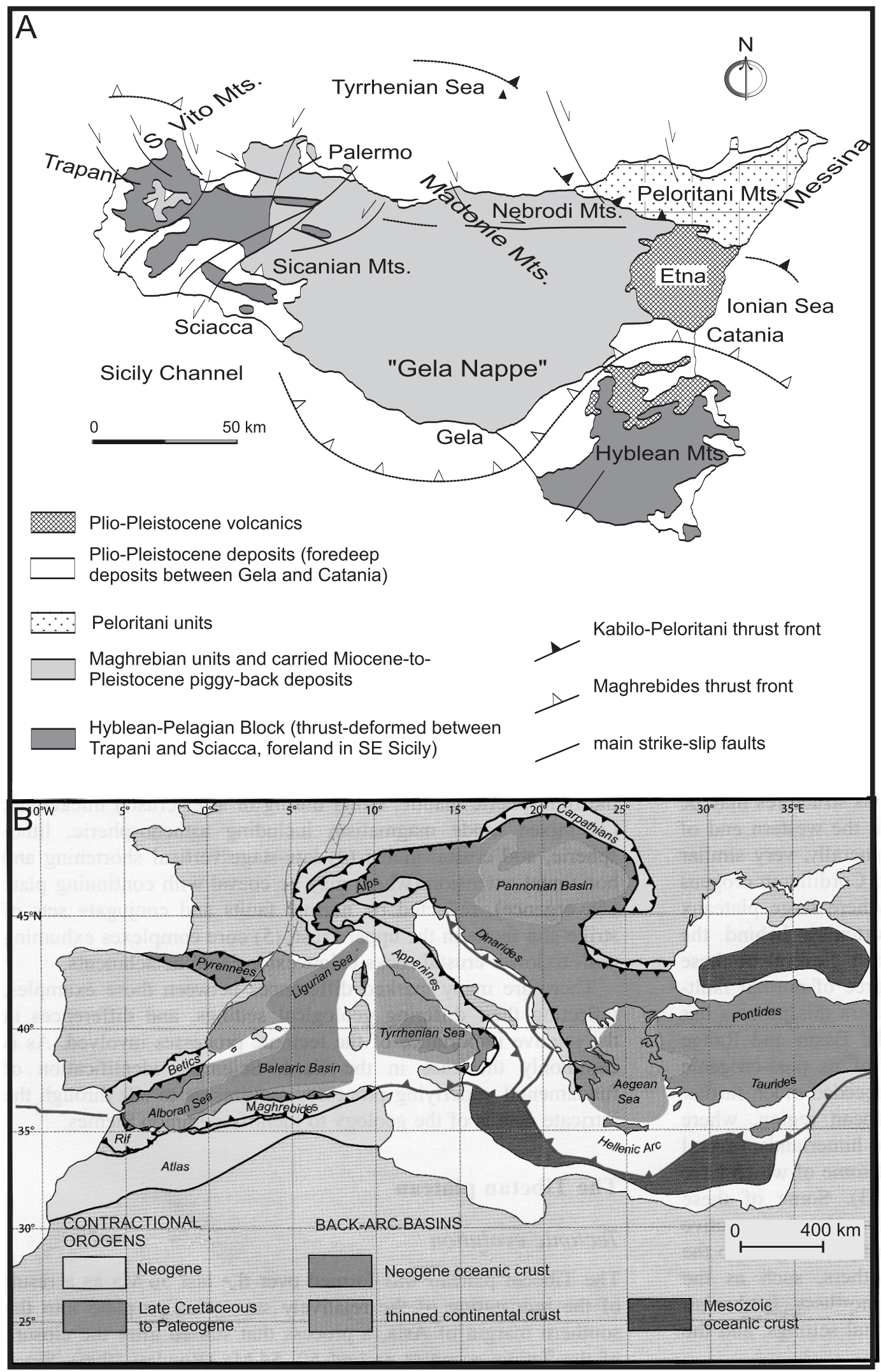

Fig. 1A - main structural elements in Sicily (modified after Nigro and Renda, 2001b); B - simplified tectonic map of the western Mediterranean region (modified after Platt, 2007) 


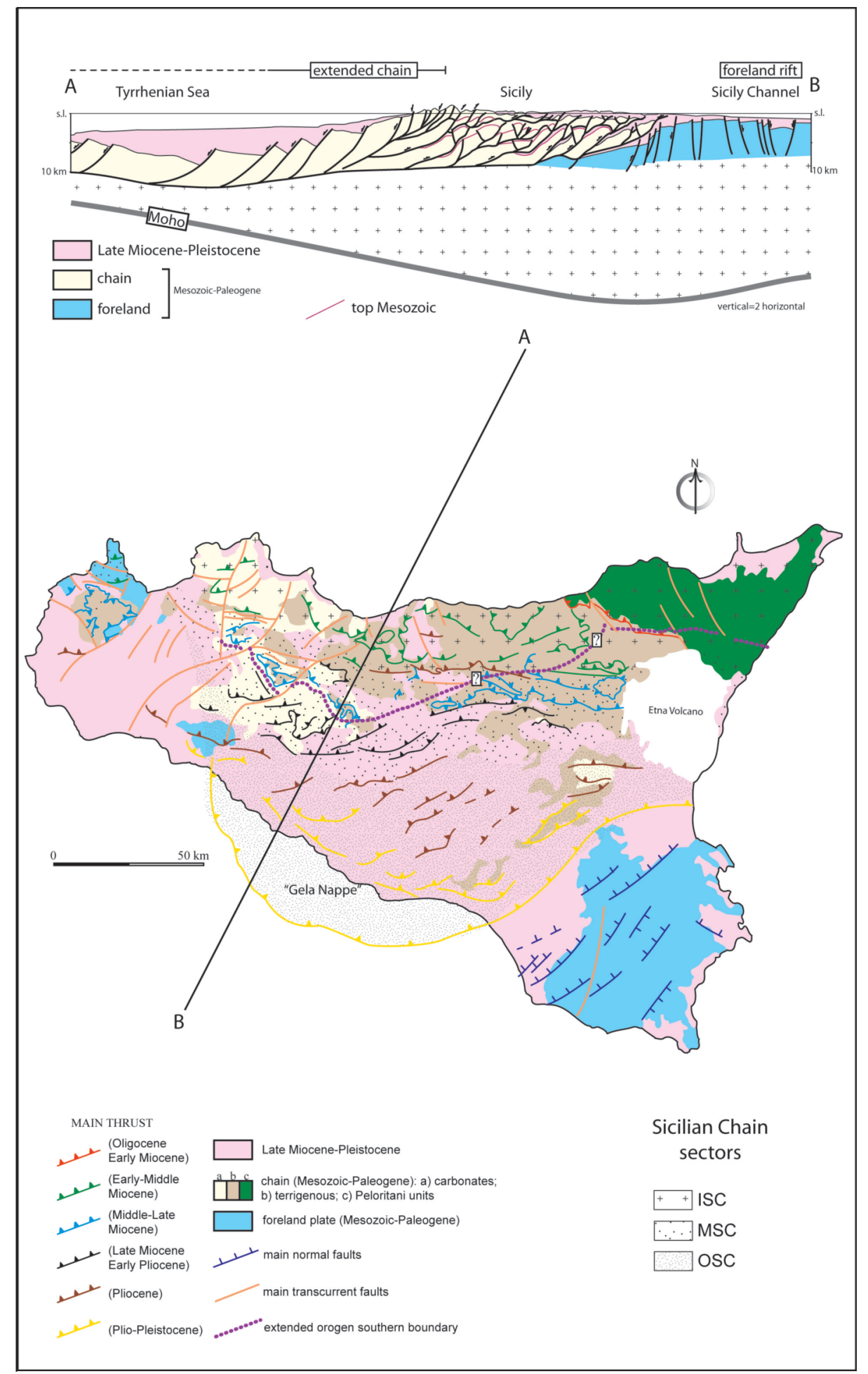

Fig. 2A - schematic cross-section (modified after Nigro and Renda, 2004a); B - structural sketch of Sicily

MSC - Middle Sicilian Chain, ISC - Inner Sicilian Chain, OSC - Outer Sicilian Chain

cretion of syn-tectonic sediments, is represented by a stack of tectonic slices. The two indenters are respectively affected by extensional deformation in southeastern Sicily, and contractional deformation in western Sicily (Finetti et al., 1996).

The thrustal system of Sicily progressively developed starting in Oligocene (Fig. 2). The tectonic units of the Sicilian
Thrust System (STS) were piled up along shallowly-dipping thrusts and were transported southwards during the construction of the Apennine-Maghrebide fold-and-thrust system (Ogniben, 1960; Scandone et al., 1974; Catalano et al., 1979; Catalano and D'Argenio, 1982; Broquet et al., 1984; Nigro and Renda, 2000). 
The STS and the Calabrian-Peloritan belt are the link between the Apennines in Italy and the Maghrebides in north Africa. The Calabrian-Peloritan belt is composed of a nappe pile of metamorphic rocks comprising ophiolitic units with their Mesozoic-Cenozoic sedimentary cover derived from the Tethyan oceanic domain (the "Liguride Complex"; Ogniben, 1973), which are overlain by a large sheet of pre-Alpine continental-derived metamorphic rocks with local remnants of a Mesozoic-Cenozoic cover (the "Calabride Complex"; Ogniben, 1973).

The arc shape of the Calabrian-Peloritan belt has been acquired during the opening of the Tyrrhenian basin since the Tortonian (Rosenbaum and Lister, 2004).

As shown by the thrusts and folds within the thrust stack of the Apennine-Maghrebide fold-and-thrust system (Giunta and Nigro, 1999), the tectonic transport direction has been changing from generally E-W to NW-SE and N-S through time (from the Late Paleogene to the Neogene). Flexural-slip folding occurred during this progressive thrusting (Oldow et al., 1990; Roure et al., 1990a, b; Nigro and Renda, 2001a). Faultpropagation-folding processes have produced widespread frontal ramp anticlines inside the thrust stack. The thrust stack shows ramp-flat geometries with a large spacing of order of hundreds metres.

Propagation of piggy-back thrusts occurred during the Late Oligocene-Late Miocene displacements. Foreland propagation of different flexural foredeep basins developed in front of the thrust belt, as revealed by the age and geometric relationships of the syntectonic deposit fills of the Oligocene-Pleistocene foredeep basins (Nigro and Renda, 2000 and references therein).

The Sicilian Thrust System is typically divided into three main domains (Fig. 2): the Inner Sicilian Chain (ISC), the Middle Sicilian Chain (MSC) and the Outer Sicilian Chain (OSC) (Tavarnelli et al., 2003; Nigro and Renda, 2004a). The ISC extends mainly in an E-W direction in northern Sicily and results from the Oligocene-Early Miocene thrust tectonics which dominated the early Africa-Europe collision (Ogniben, 1960; Roure et al., 1990a, b; Giunta, 1991; Catalano et al., 2000). The MSC and OSC mostly consist of Oligocene-Pleistocene foredeep deposits cropping out in central and southern Sicily, which were progressively involved in the contractional deformation (Broquet et al., 1966; Grandjacquet and Mascle, 1978; Giunta, 1985; Nigro and Renda, 2000) from the Serravallian on. The growth of the orogenic wedge of the STS since the Pliocene, generated by the accretion of syntectonic deposits, is represented by a stack of tectonic slices known as the "Gela Nappe" (Beneo, 1958), which belongs to the OSC.

Starting from the northern Sicily coast, a process of crustal attenuation and subsidence affected the STS since the Late Tortonian (Kezirian et al., 1994; Giunta et al., 2000).

During the Pliocene-Pleistocene time interval, dextral transcurrent faults affected northern Sicily and its Tyrrhenian offshore domains (Boccaletti et al., 1982; Finetti and del Ben, 1986). Strike-slip deformation inland was mainly accommodated by the development of an E-W-striking narrow shear zone with dextral movements (Ghisetti and Vezzani, 1984). In the southern Sicily off-shore region the submerged segments of the western and eastern edges of the Hyblean-Pelagian foreland plate are located, and have a strong structural contrast, compared to the "Gela Nappe".

The occurrence of a shortening-extension pair in the Calabria-Peloritani Arc (CPA) has been proposed and linked to the dynamics of the Apennine trench that was active during the Paleogene (Faccenna et al., 2001; Jolivet et al. 2003; Rosenbaum and Lister, 2004; Rossetti et al., 2004). Orogenic wedge dynamics (Davis et al., 1983; Platt, 1986; Willett, 1992) have been identified as a feasible scenario to frame the relationships between hinterland extension and frontal shortening in the Calabria-Peloritani Arc (Wallis et al., 1993; Knott, 1994; Thomson, 1998; Rossetti et al., 2001).

There is no a general agreement concerning the structural architecture of the CPA (Carrara and Zuffa, 1976; Cello et al., 1996; Bonardi et al., 2001; Rossetti et al., 2004; Iannace et al., 2007). Contrasting tectonic interpretations are proposed for the Early Miocene (from ca. 20 to $15 \mathrm{Ma}$ ) ages from the orogenic hinterland of the CPA, that are related either to rock exhumation during crustal thinning operated by extensional tectonics (Rossetti et al., 2004) or to rock burial during renewed orogenic construction (Iannace et al., 2007). However, extensional tectonics is documented in the Calabride Complex as being active at about $30 \mathrm{Ma}$ (Platt and Compagnoni, 1990; Heymes et al., 2008; Grande et al., 2009) concurrently with the main phase of tectonic denudation (Thomson, 1994) and the onset of exhumation of the Liguride Complex (Knott, 1994; Rossetti et al., 2001). Many points suggest that Miocene shortening of the outer units of the CPA was concomitant with extensional tectonics leading to crustal thinning and progressive unroofing of the HP-metamorphic units in the orogenic hinterland of the CPA.

\section{MESOZOIC PRE-OROGENIC STRATIGRAPHY}

The Sicilian deposits display significant facies and thickness variation, indicating that they were deposited onto differently subsiding, fault-controlled blocks (Scandone et al., 1974; Biju-Duval et al., 1977; Catalano and D'Argenio, 1982). The facies distribution reflects carbonate platforms and an intervening pelagic basin during the Mesozoic-Paleogene/Eocene time interval. From the ISC towards the south they are: Peloritani, Sicilide, Panormide, Imerese-Sicanian and Hyblean-Pelagian (Fig. 3).

Nigro and Renda (1999) indicated that the palaeogeographic domains developed on crust of different thickness. The crust was thinner beneath the Imerese-Sicanian and Sicilide basins and thick beneath the Hyblean-Pelagian carbonate platform.

From the Late Triassic onwards, shallow-water (evaporitic, lagoonal, biohermal and tidal flat) deposition occurred on carbonate platforms. In the intervening deep-water basins, finegrained carbonate deposition occurred. The carbonate platform deposition of Triassic-Early Jurassic time was replaced by pelagic sedimentation (Abate et al., 1982), onlapping above the Early Jurassic neritic strata. Siliceous limestones and bedded cherts represent the slope-to-basin plain deposition. The basin 


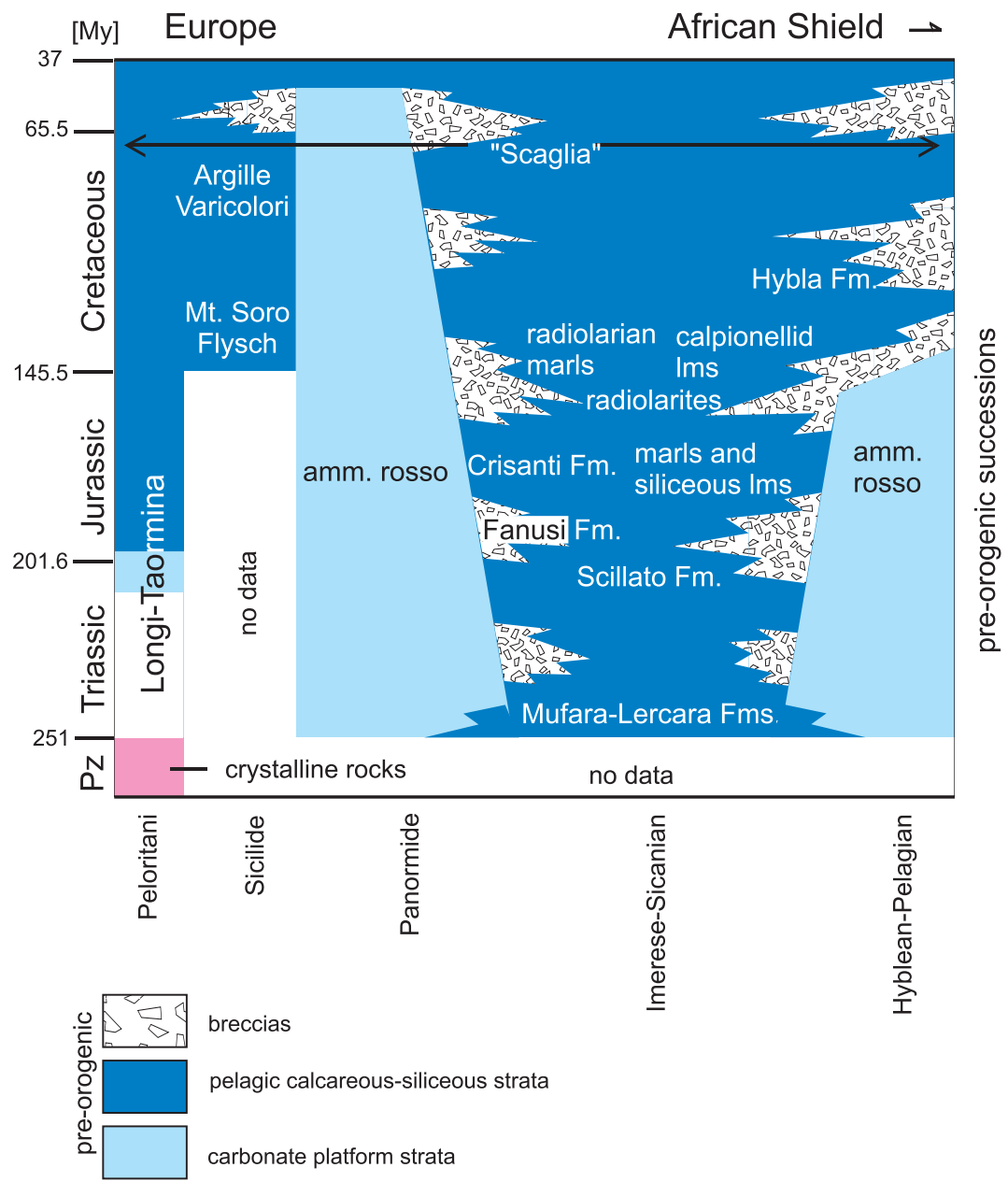

Fig. 3. Pre-orogenic lithostratigraphy sketch of sedimentary rocks in the Sicilian sector of the Sicilian-Maghrebides orogenic belt (modified after Nigro and Renda, 2005) consequence of the Sardinia-Corsica Block counterclockwise rotation (Cherchi and Montadert, 1982) - a drastic change of the sedimentary processes took place.

The collision between the Sardinia-Corsica Block and the most internal African continental margin produced, in the Maghrebide areas, foredeep systems mostly filled by siliciclastic and subordinate carbonate deposits. The STS was realized through a progressive forelandwards migration of the chain-foredeep system, progressively incorporating syntectonic deposits, which in turn carried piggy-back basins (Fig. 4). Characteristic for this stage of orogenesis is the development, in migrating foredeep basins, of olistostromes and olistoliths derived from the front of advancing nappes of the ISC (Beneo, 1958; Flores, 1959).

The distribution of the syntectonic facies associations (Nigro and Renda, 2000 and references therein) allow reconstruction of a prograding turbiditic fan system developed in the inner foredeep edge from the Oligocene to the Late Miocene (Fig. 5). Distal turbiditic bodies filled the axial zone of the foredeep, while its outer edge saw foreland carbonate and/or pelagic sedimentation (Fig. 4). Figure 5 outlines the facies distribution of the inner-axial-outer foredeep-foreland system (including piggy-back deposits) for six time intervals. During the Late Oligocene-Early Miocene (Fig. 5A) the ISC built up and during the Langhian-Middle Tortonian (Fig. 5B) the MSC was progres-

slopes were characterized by re-sedimentation processes, expressed as thick bodies of dolomitic breccias and olistostromes with olistoliths interbedded within the pelagic deposits at different stratigraphic levels.

Jurassic dykes are commonly observed within the carbonate platforms (Wendt, 1965; Truillet, 1966; Mascle, 1970, 1979; Bernoulli and Jenkyns, 1974; Bouillin et al., 1992; di Stefano et al., 2002).

Jurassic-Early Cretaceous deposition is represented by condensed and deep-water deposition above the neritic strata. Starting from the Late Cretaceous, carbonate platform deposition was drastically reduced in Sicily. Deposition reflects a progressive physiographic uniformity, represented by basin-plain marly limestones, progressively lying over the pelagic deposits and the fragmented neritic carbonates. Late Cretaceous sedimentation is also represented by turbidites and deep-water deposits of the so-called Sicilide Basin.

\section{NEOGENE SYN-COLLISIONAL STRATIGRAPHY}

By Late Oligocene onwards, inversion tectonics and thrusting of the innermost African continental margin started, as a sively developed.

From Late Tortonian to Early Pliocene time (Fig. 5C-E) sedimentation was affected by extensional deformation (see Figs. 8, 9 and next paragraphs) and evolved from mostly clastic in the Tortonian, to evaporitic in the Messinian and to pelagic in the Early Pliocene.

During the Plio-Pleistocene (Fig. 5F) the OSC built up.

\section{CONSTRAINTS FOR OLIGOCENE-PLEISTOCENE FOREDEEP-FORELAND SYSTEM MIGRATION}

On the basis of syntectonic sedimentary facies distribution and the geometric relationships between the tectonic units of the STS, a deformation chronology during the Late Paleogene-Neogene may be summarized as follows:

1. Starting from the Late Oligocene, the incipient opening of the Ligurian Basin and Sardinia-Corsica Block rotation (Cherchi and Montadert, 1982) induced a progressive change of the African Continental Margin physiography, connected to the early deformational stages affecting the inner Peloritani domains. Thus, the inner Sicilian carbonate platforms/basins were progressively involved in the collisional deformation (ISC displacements). A foredeep-foreland system developed (Numidi- 


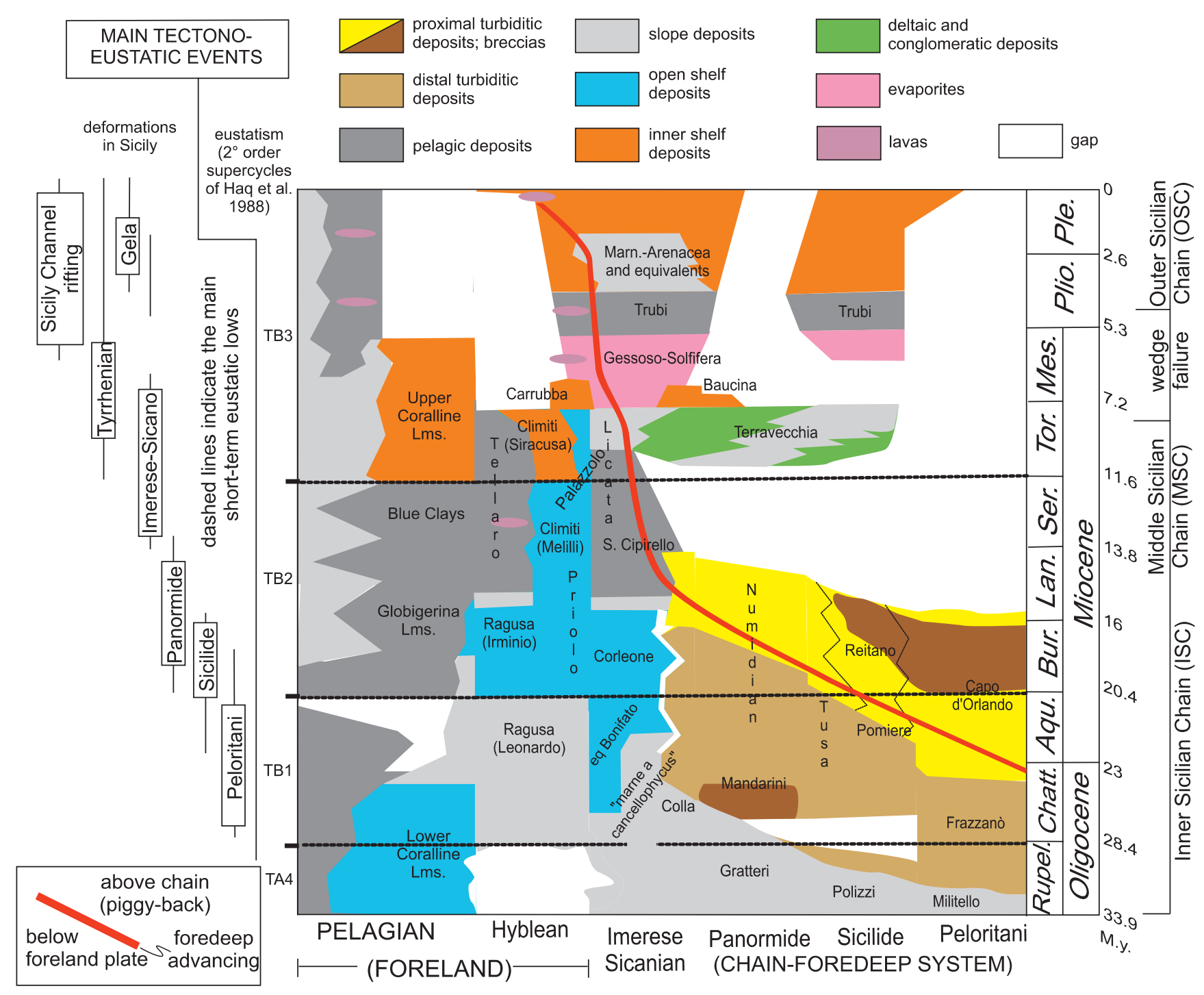

Fig. 4. Syn-collisional stratigraphy of sedimentary rocks in Sicilian sector of the Sicilian-Maghrebides orogenic belt

Different distribution of the foredeep-foreland facies during the displacement of the Sicilian Thrust System, and the main tectono-eustatic events

an Basin; Giunta, 1985). Its internal edge was filled by terrigenous syntectonic deposits. The Numidian foredeep was included in the ISC from the Late Langhian (Pescatore et al., 1987), when the Sicilide Basin deformation took place, with its emplacement over the Panormide sectors and of both over the internal sector of the Imerese-Sicanian Basin.

2. During the Serravallian-Middle Tortonian the MSC built up. The Numidian foredeep was completely involved in the MSC building. The foredeep basin migrated forelandwards, as a consequence of the progressive deformation of the Imerese-Sicanian Basin. The outer foredeep edge developed on the Imerese-Sicanian successions, where the sedimentation began to acquire a clastic contribution deriving from the erosion of the uplifting ISC and MSC thrust sheets.

3. During the Late Tortonian-Messinian, the ISC and MSC thrust stacks were partly emergent (Peloritani, Sicilide, Panormide and internal Imerese-Sicanian deformed domains).
Extensional deformation affected the chain-foredeep-foreland system. Sedimentation filled intramontane basins (Abate et al., 1988). In the axial-outer foredep basin of the MSC, marine sedimentation again acquired a clastic contribution deriving from erosion of the chain. In the emerging internal chain body, evaporitic deposits filled the Tortonian extensional basins, while in the MSC foredeep they also filled several perched basins on the back of the piled-up tectonic units (outer Imerese-Sicanian Basin and Hyblean-Pelagian margin p.p.).

4. From the Early Pliocene, the youngest OSC suffered renewed thrusting. Marly and sandy sedimentation developed on the Hyblean-Pelagian margin, which continued to inflect because of chain loading, thus promoting the Plio-Pleistocene foredeep development, forming the Valle del Belice Foredeep (Vitale, 1990). Thrust and fold tectonics completely affected the Imerese-Sicanian Basin and the Hyblean-Pelagian margin in western Sicily. 


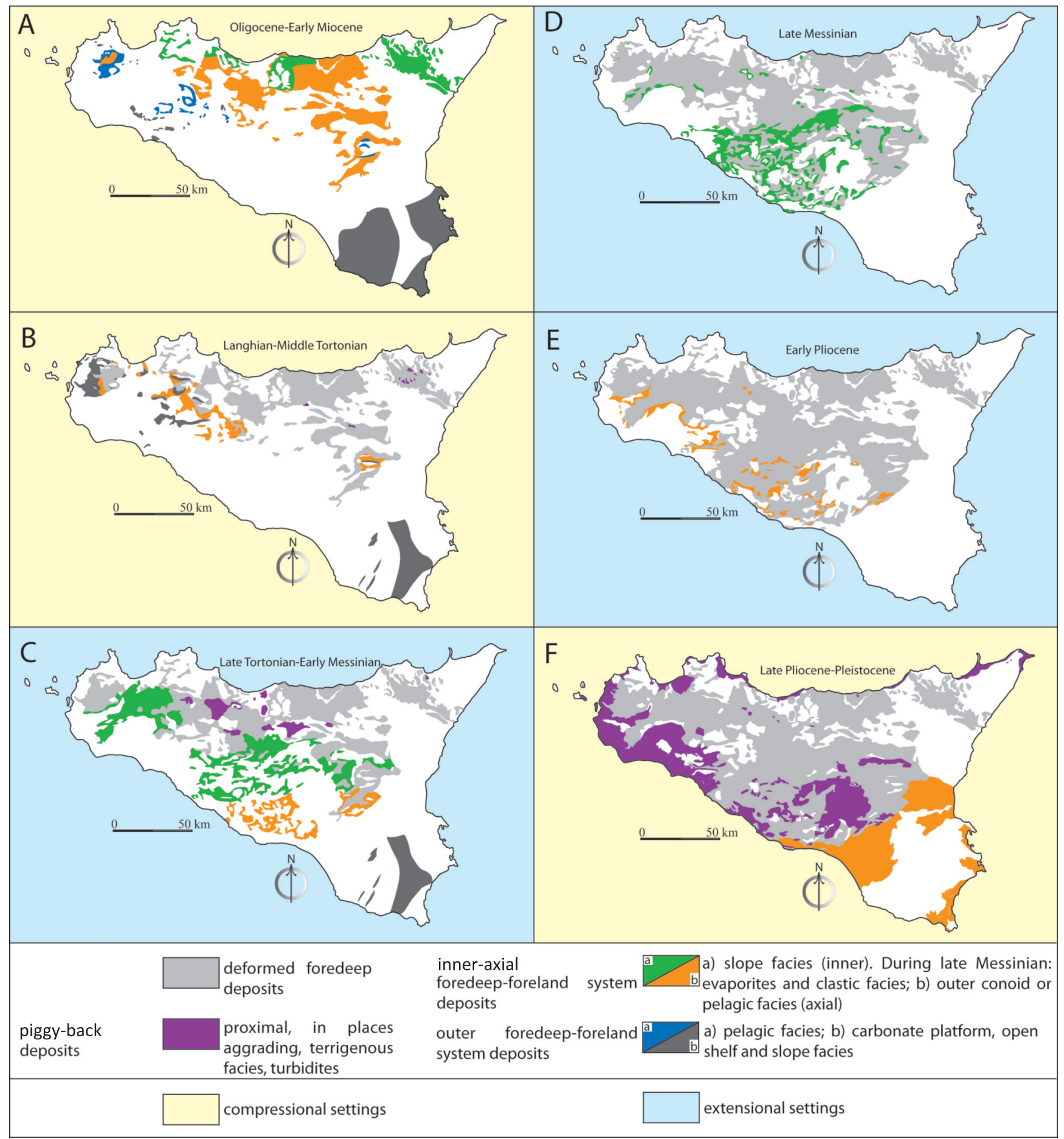

Fig. 5. Distribution, in the Sicilian Thrust System, of the facies of the foredeep-foreland and piggy-back deposits from the Oligocene to the Pleistocene that underwent a sequence of contractional and extensional events

\section{STRUCTURAL PATTERN}

Neogene thrust tectonics had an oblique component of movement, as suggested by the palaeomagnetic data of Oldow et al. (1990), who recognized a progressively clockwise rotation of thrust sheets during their evolution.

The structural data provide evidence for kinematic constraints on oblique thrust stacking in Sicily (Nigro and Renda,
2002). The relationship between the amount of shortening during oblique convergence and the uneven shape of the foreland plate deflected trajectories near the foreland indenter template, whose lateral margin acted as a regional-extended oblique ramp during contractional strain.

The outcrop-scale contractional structures are not uniformly distributed in the STS throughout the deformed multilayer. The non-uniform horizontal distribution of the contractional structures from the hinterland to the foreland is consis- 

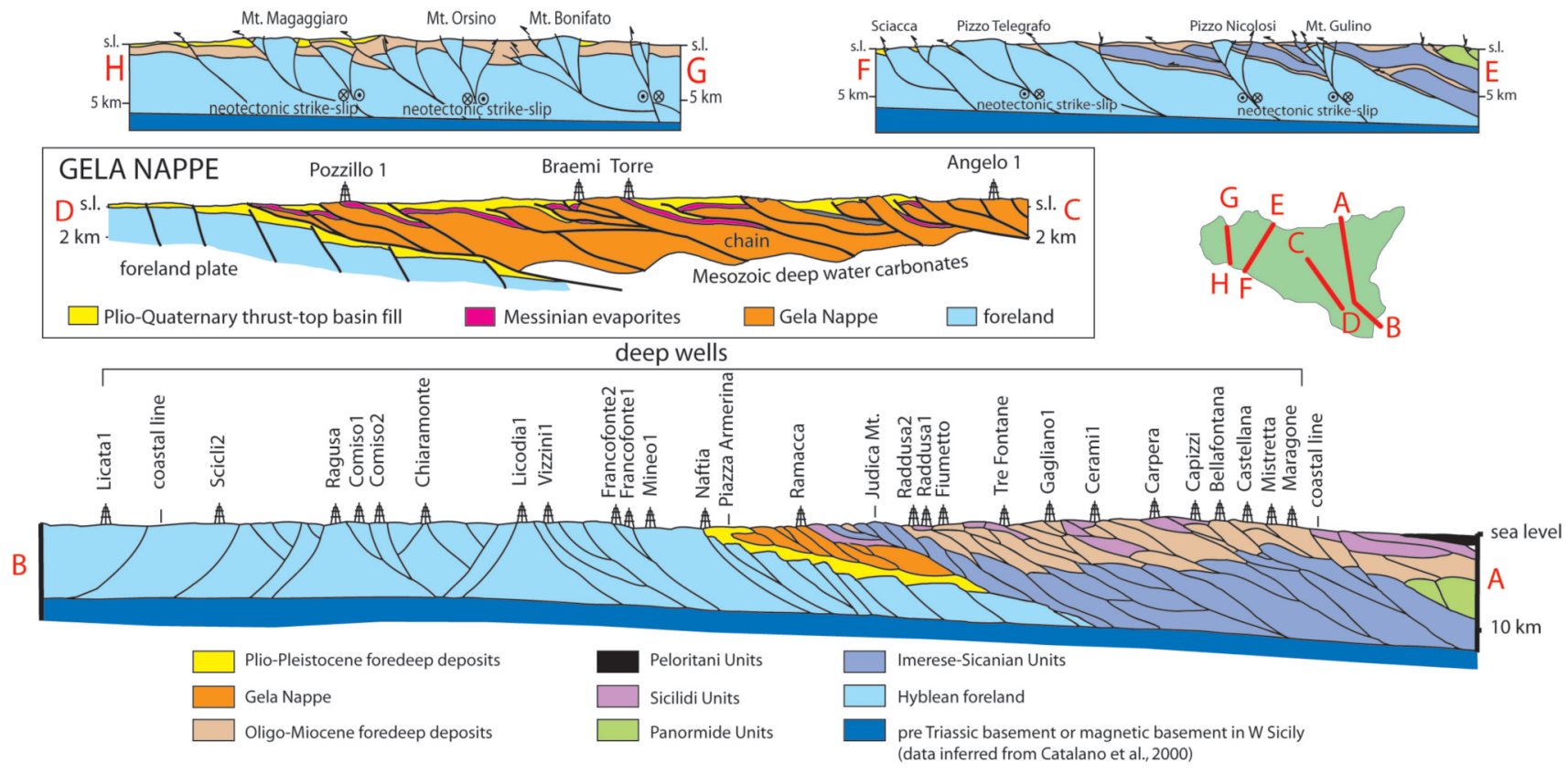

Fig. 6. Examples of geological cross-sections from the northern part of the Sicilian Thrust System

tent with the strain partitioning rate, decreasing in pervasive characters forelandwards. In fact, overprinting relationships of outcrop-scale structures are much better developed in the ISC than in the MSC and OSC, and there is more displacement (Catalano et al., 1977; Lickorish et al., 1999). Otherwise, its vertical non-uniform distribution may reflect control by mechanical anisotropy of the multilayer.

Compressional stress on a mapscale is represented by the development of a set of thrust sheets, characterized by frontal ramp anticlines, and splays. The general strike of axial planes of contractional structures indicates an African vergence of these structures. The cross-sections in Figure 6 show the collisional geometries of both the eastern and western sectors of the STS, including the so-called "Gela Nappe".

Within the ISC, thrusts dip towards the NW in western Sicily, towards the $\mathrm{N}$ in the middle sector of northern Sicily and towards the NE in NE Sicily. In western Sicily, the STS largely overthrusts the deformed external shallow substrate with a very low angle of the thrust planes (Catalano et al., 2000; cross-section E-F of Fig. 6). Thrust step-up geometries are characterized by only a few degrees of dip. Forelandwards, the STS link along a sole thrust and show more highly thrust step-up angles of reverse faults. The deformed foreland is affected by an emergent reverse fault system in SW Sicily, where thrust step-up geometries are characterized by very high values of dip (cross-section H-G of Fig. 6). In western Sicily, the edge of the foreland plate is strongly affected by contractional structures (cross-section $\mathrm{H}-\mathrm{G}$ of Fig. 6), where the Imerese-Sicanian units (pelagic basin rocks of the OSC) thrust over the Hyblean-Pelagian carbonate platform, made of slope facies successions (cross-section E-F of Fig. 6). This sector of the OSC is dominated by thin-skinned thrusts, with ramp-flat geometries and moderate spacing of the sheets of the order of tens or hundreds of meters. Step-up angles progressively increase from pelagic to carbonate platform successions, due to both flat and ramp development. Detachments inside the multilayer provide examples of multi-harmonic folding, splays and duplex geometries. Duplex geometries are more evident in eastern Sicily (ISC and MSC p.p.; cross-section A-B of Fig. 6) than in western Sicily. Thrust spacing, as well as shortening, increases abruptly eastwards. In the Caltanissetta Basin (central Sicily), the inner tectonic units (the so-called Sicilidi) are superposed onto the Imerese-Sicanian units, suggesting a greater amount of contraction in the centre of the MSC (p.p.) and OSC belts.

Due to compressional stress, the foreland plate of western Sicily is deformed by high-angle faults both oriented on-land and in the off-shore of southern Sicily, where Plio-Pleistocene sequences are involved in the contractional deformation. Positive inversion of pre-orogenic normal faults occurred in places during chain building, in the ISC and MSC and in the foreland plate (Fig. 7).

Extensional deformation is mostly represented by low-angle detachment systems dipping in to the chain, which have back-slid the tectonic units (Giunta et al., 2000). The common fault linkage of the normal fault ramp segments with the contractional shears and thrusts suggests that negative inversion of the tectonic units was the dominant process as regards the extensional stresses (Figs. 7 and 8), allowing stretching and STS thinning. Normal faults are recognized at different scales, from $1 \mathrm{~m}$ to several kilometres. The main ramp segments determine the outcropping fault steps which segmented the thrust stack and allowed the lowering of the STS orogenic belt towards the Tyrrhenian Sea.

\section{MODES OF INVERSION TECTONICS}

Reactivated structures may represent the effects of inversion tectonics and may transform basin subsidence into uplift 


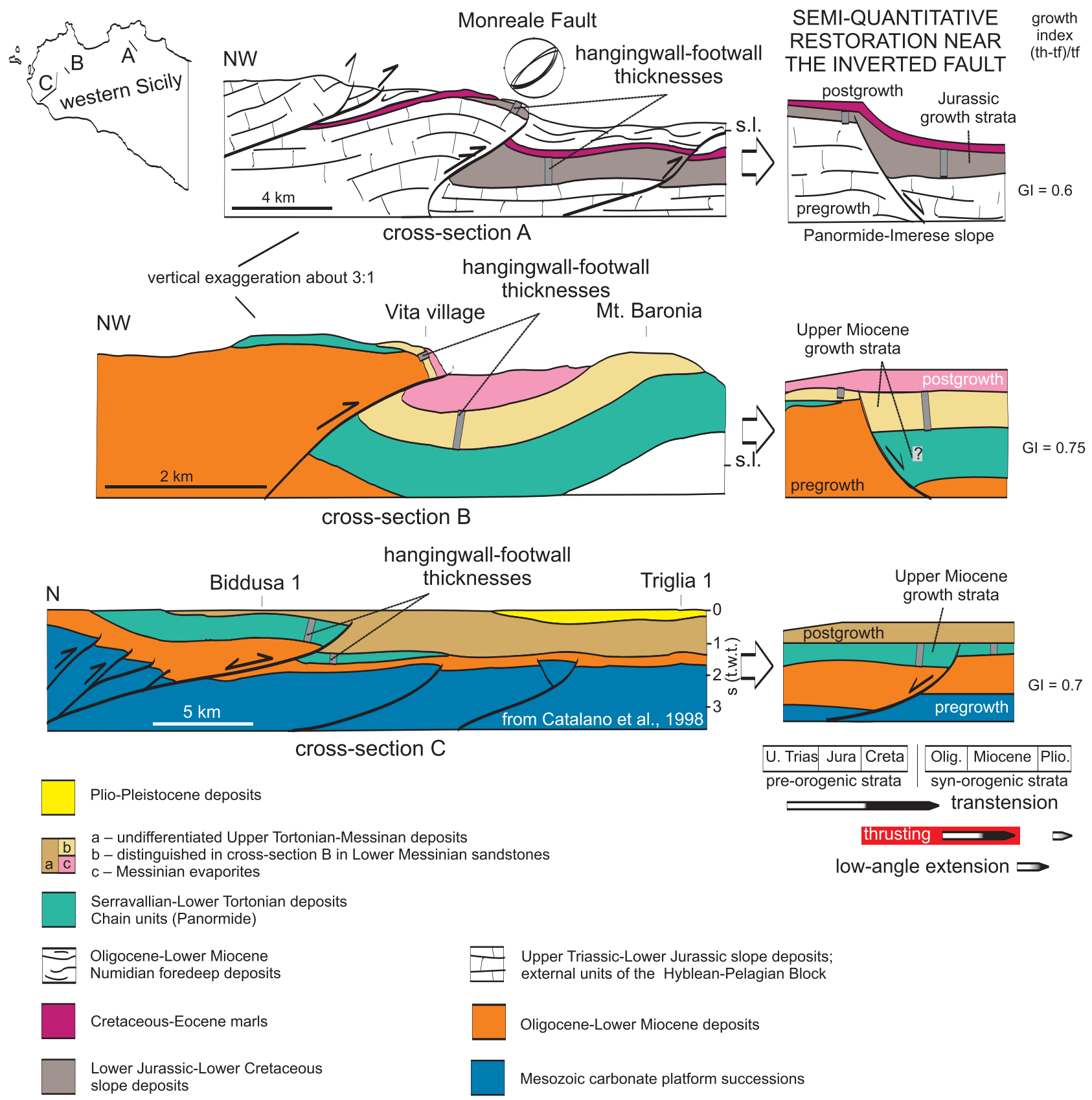

Fig. 7. Examples of positive inverted structures in western Sicily (ISC and deformed foreland plate)

The GI on the right-hand side is the growth index, defined as (hangingwall-footwall thicknesses)/footwall thickness; note the opposing dip change of the Monreale Faults in cross-section A, and the same sense of displacements (normal), although reverse slip is demonstrated by the compressional structural relief (modified by Giunta et al., 2002)

with generation of folds and thrusts. Inversion tectonics may act from extension to compression (positive inversion) or from compression to extension (negative inversion; Williams et al., 1989; Sciscianni et al., 2002).

\section{POSITIVE INVERSION}

The main geometric feature of the positive inverted structure is the complex variation in stratigraphic separation along the main faults of the STS. The separation pattern is overall exhibited by the lateral thickness variation of the syn-extensional growth lithological unit in the hanging-wall and in the foot-wall near the re-activated reverse fault, which cannot be balanced with only one slip motion. Examples of positively reactivated structures recognized in western Sicily are shown in Figure 7. The cross-sections exhibit different-scale reverse faults involving Mesozoic-to-Upper Miocene successions; their semi-quantitative restorations and the mesostructural data provide evidence of inversion of fault-plane motion. The fault dip with respect to the tectonic transport direction should indicate younger geometry modification. Cross-section A was drawn across the ISC, and cross-sections $\mathrm{B}$ and $\mathrm{C}$ across the foreland plate. 
A
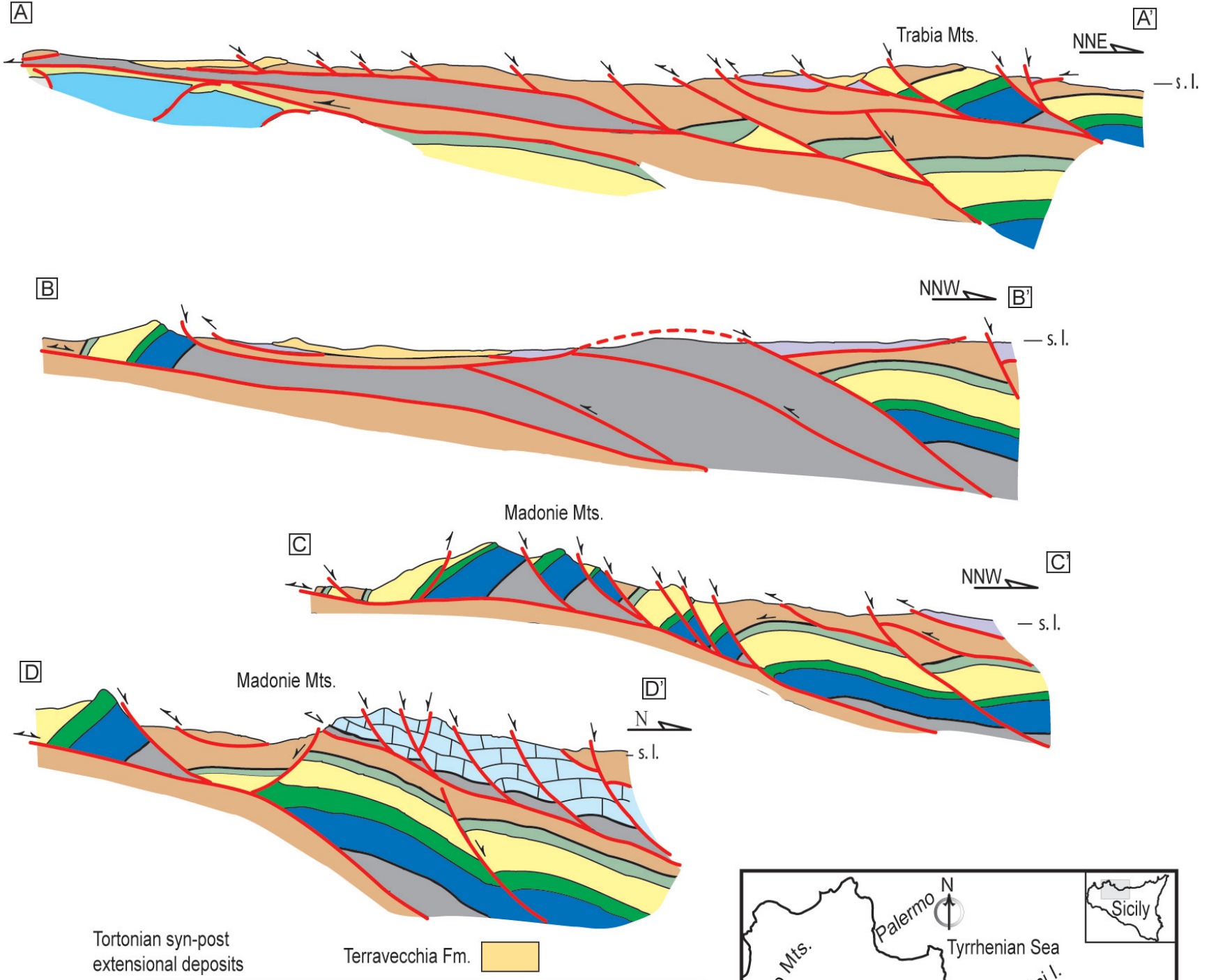
extensional deposits

Tertiary foredeep Numidian Flysch $\square$ Serravallian shales $\square$
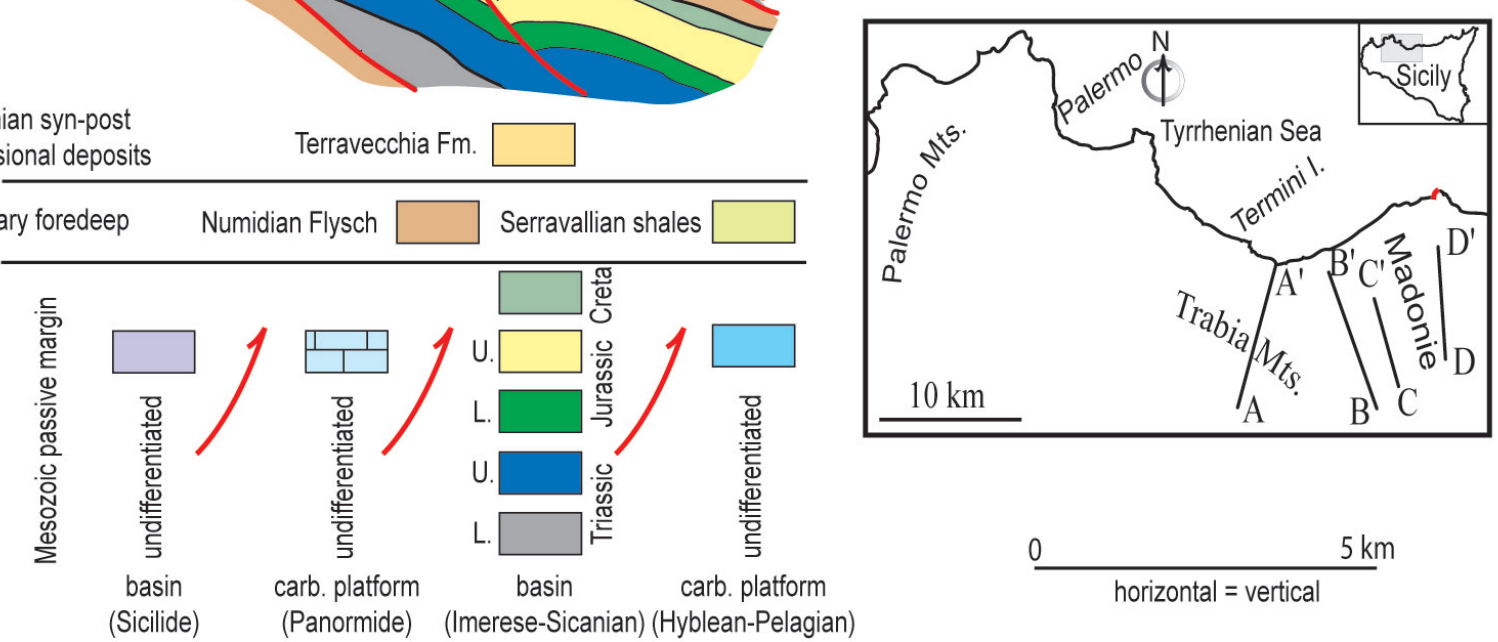

Fig. 8. Geological cross-sections in the ISC, depicting several examples of negative inversion during the Late Miocene

North-dipping extensional ramps linking along shallow flats are very common; in places, extension determined the exposure of geometrically deeper strata in a younger-on-older geometry; Late Tortonian and Messinian deposits unconformably overlie these structures

Extensional deformation occurred both in the Mesozoic, during the passive margin evolution, and after the Neogene compressional deformation. Mesozoic extensional tectonics is revealed both by facies associations and by thickness changes along the carbonate platform-pelagic basin slopes and by alkali-basaltic effusions within the slope-basin plain successions. During the Neogene compressional tectonics, the strain partitioning was often controlled by the inherited weakening of carbonate platform-pelagic basin boundaries, as suggested by the thrust geometries (Lickorish et al., 1999; Nigro and Renda, 2002). 


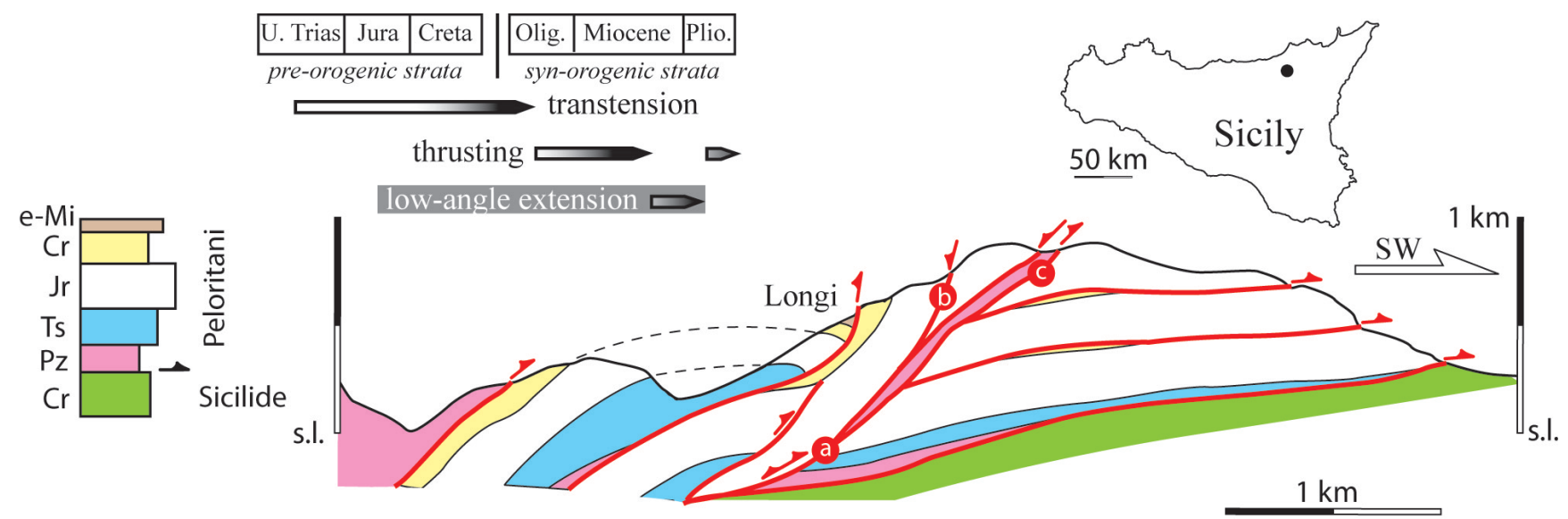

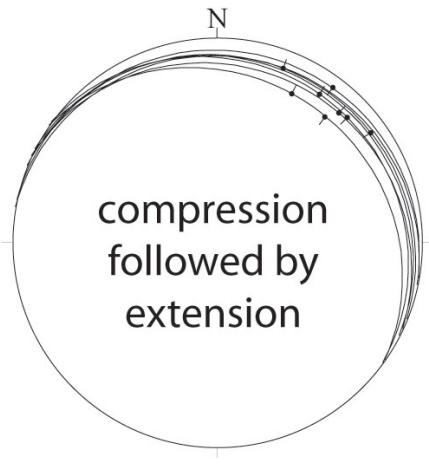

a

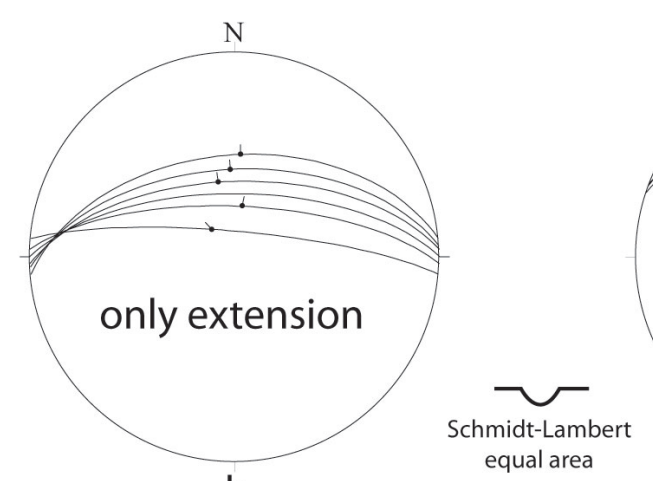

b

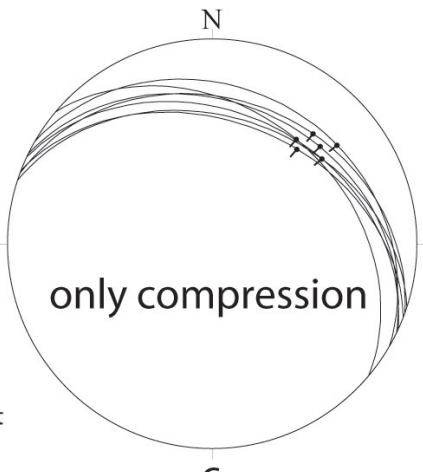

C

Fig. 9. Example of negative inverted structures in northeastern Sicily (ISC)

The superposition of calcite fibres and slickensides along the master fault surfaces (site a) suggests thrust negative inversion coupled with a new generation of normal faults (site b); the reverse fault segments preserved from the negative reactivation often coincide with the front of the tectonic unit (site c) (modified after Nigro and Renda, 2004b)

Extensional tectonics affected the Neogene foreland synchronously to the thickening of the Sicilian wedge-shaped chain both of the ISC and MSC. The related structures were also inverted due to the outward propagation of the STS thrust front.

\section{NEGATIVE INVERSION}

Synorogenic extension has been recognized in northern Sicily. The extensional deformation is mainly represented by low-angle detachments and shear bands. A common kinematic process seems to have affected the other sectors of the STS during extension and is represented by a generalized negative inversion of previous layer-parallel shear bands and detachments related to the thrusting. The extensional deformation occurred during the Late Miocene. It significantly modifies the older architecture of the STS through the sliding back of the tectonic units.

Figures 8 and 9 outline some examples of negative inversion of thrust faults, mostly within the ISC and in part within the MSC. The cross-section of Figure 9 was drawn across NE Sicily (ISC) and shows the overprinting relationships between thrusts and normal faults. The collected mesostructural data reveal partial reactivation (negative inversion) of thrust surfaces (site a) and contemporaneous new generation of normal faults (site b), linking down-section along previous mechanical discontinuities. The cross-sections of Figure 8 were drawn across western Sicily (ISC). The normal fault ramps generally link down-section along the Lower Miocene thrust planes, which were reactivated and later inverted. The listric-like geometry of the extensional faults is expressed by tilting of blocks (section A-A'). They deform with high angle the Mesozoic-Eocene carbonates, and with low angle Oligo-Miocene foredeep deposits. Extensional ramp faults, inducing tilting of Jurassic carbonate blocks, link along the older thrust surfaces (section $\left.\mathrm{C}-\mathrm{C}^{\prime}\right)$. Accentuation of hangingwall tilting is in places revealed by roll-over geometries, where portions of older tectonic units backslide along thrust surfaces. The trend of these structures has a main peak of frequency towards the NW-SE, swinging to an $\mathrm{E}-\mathrm{W}$ direction. The thrust system overall gently dips towards the N-NE. The listric ramp-flat extensional faults are superimposed onto a tectonic edifice and have inverted the older thrust surfaces. Extensional detachments locally determine tectonic omissions in the frontal portions of the negatively inverted thrust, as indicated by tectonic superposition of the Oligo-Miocene foredeep deposits over the Lower Triassic deposits of the Imerese-Sicanian Basin (section B-B'), in a younger-on-older geometry. 


\section{POST-MIOCENE RENEWED THRUSTING IN THE ISC AND MSC}

In the ISC and MSC p.p. thrust sheet geometries overprint the Late Miocene extensional faults and deform the Early Pliocene deposits (cross-sections B and C of Fig. 10). This thrust generation is coeval to displacements of the OSC in central-southern Sicily.

Cross-sections of Figure 10 show post Late Miocene-Early Pliocene thrust geometries. The ISC suffered renewed thrusting allowing the "inversion" of the geometric relationships between the Sicilide Basin and the Oligocene-Lower Miocene foredeep deposits (section C). Ramp-flat geometries characterize the renewed thrust system, that displace the older one, in places buried by the Upper Miocene perched deposits (crosssection A) and inducing folding of Miocene faults (section B). The Pliocene thrust system affected the ISC-MSC thick skins of the already emplaced chain in an out-of-sequence forelandwards migration.

\section{BOREHOLES DATA}

Data from sixteen boreholes have been analysed to better constrain the surface data of thrust timing in the STS (Fig. 11; borehole data are available from Regione Sicilia, Assessorato Industria). The boreholes are distributed across the ISC, MSC and OSC. Borehole stratigraphy has been collected featuring pre-orogenic strata, foredeep and foreland strata. Also, the foredeep was featured in the Oligocene-Middle Miocene (ISC emplacement), Middle-Late Miocene (MSC emplacement) and Plio-Pleistocene (OSC emplacement). The thrust timing is the same as in Figure 11. The position of the out-of-sequence thrust of Figure 10 is also shown.

In the ISC, the Oligocene-Middle Miocene foredeep deposits were incorporated in the collisional wedge between the Early and Middle Miocene (boreholes 7, 8 and 16). In the MSC, the Middle-Late Miocene foredeep deposits were incorporated between the Middle-Late Miocene and the Early Pliocene (boreholes 4, 5, 12,13,14 and 15), whereas in the OSC the

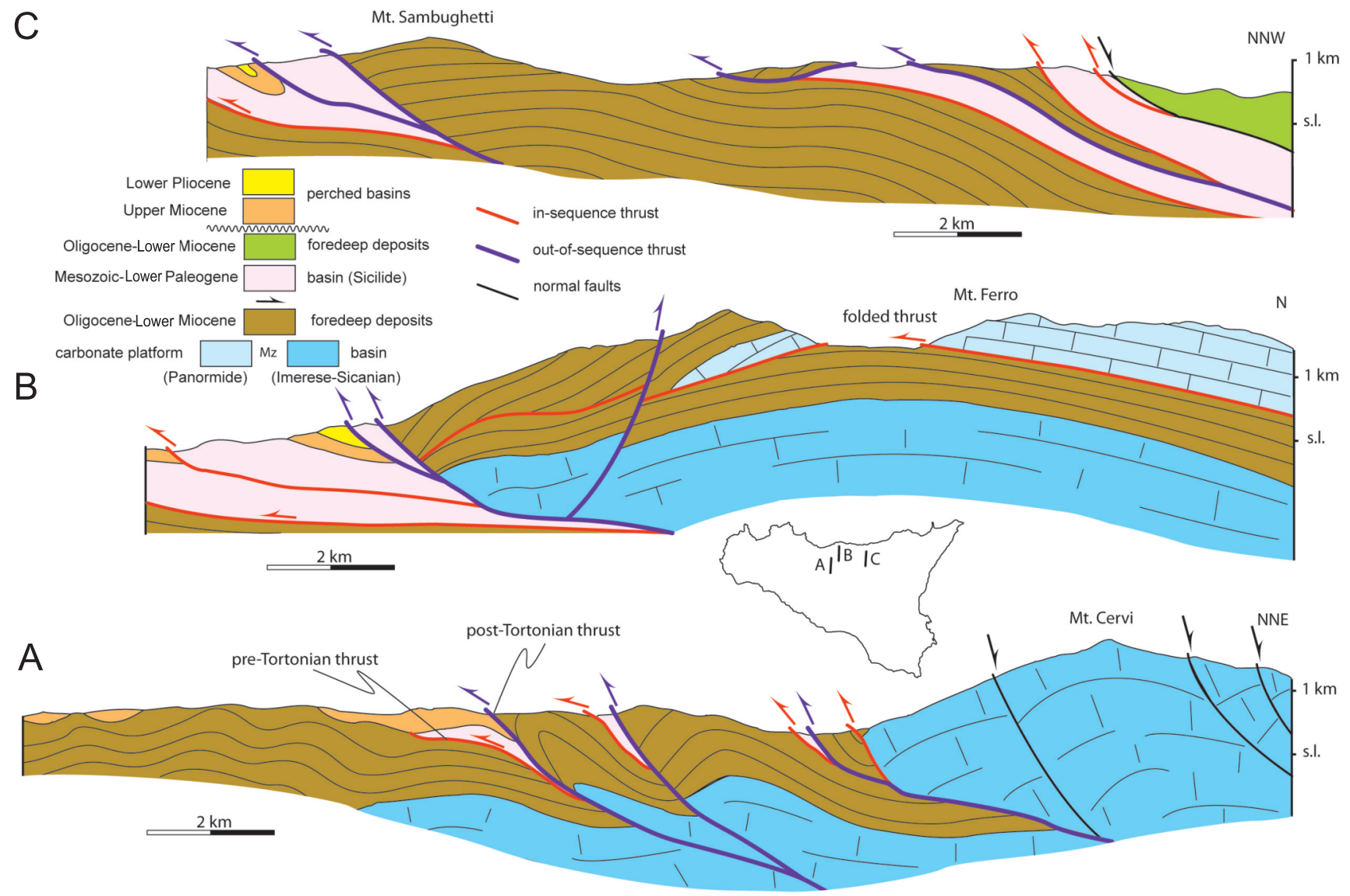

Fig. 10. Geological cross-sections (A, B, C) across the ISC and MSC depicting the structural pattern acquired during the post Early Pliocene compression

Out-of-sequence reverse faults cross-cut previous thrusts and in places are involved in the shortening of the Early Pliocene deposits; fault overprinting may also determine thrust folding, as depicted in the rectangle 


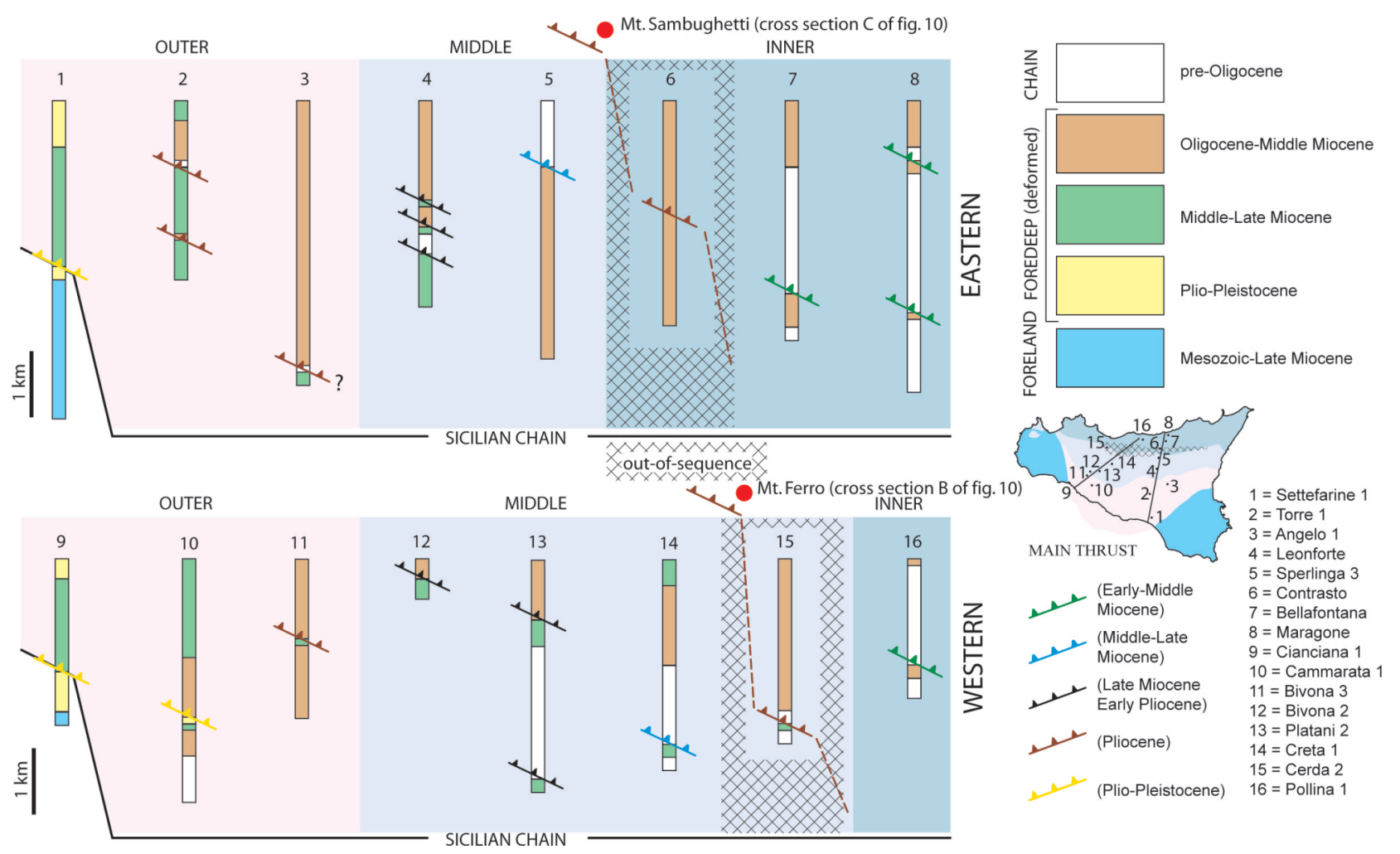

Fig. 11. Stratigraphic data from 16 selected deep boreholes located in the ISC, MSC and OSC

The foredeep deposits were assembled in the Oligocene-Middle Miocene (ISC emplacement), Middle-Late Miocene (MSC emplacement) and Plio-Pleistocene (OSC emplacement); thrust timing is also outlined within the outcrop data of Figure 10, suggesting out-of-sequence deformation suffered by the ISC-MSC sectors of the STS

foredeep deposits were incorporated during the Plio-Pleistocene (boreholes 1-3 and 9-11).

Thrust timing reflects an overall in-sequence forelandwards migration of the chain front. Between boreholes 14-16, out-of-sequence thrust propagation confirms the surface data of Figure 10, suggesting that the earlier shortening of the ISC-MSC is coeval with the OSC emplacement and post-dates the Late Miocene extension.

\section{DISCUSSION}

The Neogene tectonics of the central Mediterranean are related to the subduction and trench rollback of the Ionian Basin under Eurasia, causing the opening of the Liguro-Provencal and Tyrrhenian back-arc basins and the formation of the Calabrian accretionary wedge. In the central Mediterranean, subduction is primarily related to intermittent trench retreat producing back-arc extension at an average rate of a few centimetres per year, and to a lesser degree to the slow convergence between Africa and Eurasia. The latter usually did not exceed $1 \mathrm{~cm} / \mathrm{yr}$ (Jolivet and Faccenna, 2000; Faccenna et al., 2001). Extensional deformation accompanied the growth of the accretionary wedge in the back-arc region
The stratigraphic and structural data allowed demonstration of fold-and-thrust belt evolution in the STS as follows:

1. In-sequence thrust stacking and folding from the Oligocene to the Late Miocene (ISC and MSC emplacement);

2. Extensional deformation from the Late Miocene to the Early Pliocene (thinning of the ISC, MSC and foredeep-foreland systems);

3. Renewed thrusting from the Pliocene, allowing out-of-sequence thrusting in the ISC and MSC p.p. and the emplacement of the OSC.

Our results provide new insight into the style of accretion in a weakly convergent setting, which is typical for the Mediterranean region. So as to be able to fully understand the kinematic history of a mountain belt, in terms of strain partition (in the interplay of compressional and extensional forces), the variation in crustal thickness of the foreland plate and the ratio between the shortening and lengthening rates must be evaluated.

The development of an orogenic wedge during continental collision results in the thickening of the crust. The excess mass of this thickened crust acts as a load on the underthrust plate, causing it to flex downwards close to the load, thus developing a foreland basin (Beaumont, 1981; Sinclair and Allen, 1992).

The variation in thickness of the STS foreland plate has been described by Nigro and Renda (2001a, 2002), who portrayed STS fold-and-thrust belt geometry in terms of foreland 
indenter shape and non-uniform crustal thickness, because these latter exert firm control over strain partition during chain building, which results in regional-scale oblique thrusting.

The foredeep-foreland system of the STS migrated outwards with respect to the orogenic front from the Oligocene onwards (Nigro and Renda, 2000; Fig. 6). This suggests progressive loading and flexuring of the underthrust plate. Moreover, Pedley and Grasso (1992) argued that the progressive bounding and chain-dipping faulting of the outer foredeep edge was to be referred to thrust stack thickening and migration forelandwards.

The innerwards thickening of the STS, outlined in Figure 6, is consistent with progressive crustal loading during thrust front migration forelandwards.

The wedge-shape geometry of the STS has also been described by Bello et al. (2000) on the basis of deep seismic reflection data. They refer to post-Miocene thrusting which allowed for deep duplex geometries (and crust thickening), that involved the foreland plate through underplating mechanisms.

Lavecchia et al. (2007) also described the crustal geometry of Sicily using seismic data. They described the large internal structures of the STS wedge-shape, deducing that the basal décollement, as well as several thrust and/or normal faults, are still active. They also portrayed negative inversion of thrust faults in the ISC and MSC.

The implication of treating accretionary wedge complexes on convergent tectonic margins by continuum mechanics as weak wedge-shaped bodies above a décollement surface leads to two predictions:

- deformation within the wedge may include large amounts of horizontal extension as well as shortening;

- extensional deformation may take place while plate convergence is continuing and before continental collision (Wallis et al., 1993).

Wedge thickening may be analysed by taking into consideration the sedimentary signal of the foredeep deposits, in terms of the distribution of facies and thickness. Figure 12 outlines the tectonic evolution of the Sicily Belt in terms of involvement of the preorogenic strata and their relationships with the foredeep-foreland system:

1. During the Oligocene-Early Miocene the foreland plate was represented by the Hyblean-Pelagian Block and the outer Imerese-Sicanian Basin. The ISC emplacement induced crustal loading. A peripheral bulge was formed in the foreland plate. The thickness of the foredeep deposits decreased forelandwards.

2. During the Middle-Late Miocene further chain thickening and loading (MSC emplacement) induced increases in the peripheral bulge in the foreland plate. The fault-controlled foreland-foredeep margin was reactivated, as suggested by Nigro and Renda (2005), thus determining subsidence and then accommodation space for the foredeep basin fills that were higher than in the chain toe. The thickness distribution of the MSC-related foredeep deposits increased forelandwards.

3. During the Late Miocene-Early Pliocene, generalized extensional deformation thinned the chain-foredeep system.

Geodynamic reconstructions suggest that extension started during the Early Oligocene with the opening of the LigurianProvençal Basin, accommodated by counterclockwise rotation of the Corsica-Sardinia Block (Westphal et al., 1976; Vigliotti and Langenheim, 1995; Rollet et al., 2002). Closer to the former European southern palaeomargin, in the Calabrian-Peloritan belt (Rossetti et al., 2004, Platt and Compagnoni, 1990) reported Oligocene-Miocene extensional tectonics, the geometry of which has recently been clarified by Heymes et al. (2008, 2010): all across the Calabrian-Peloritan belt, its direction is NNE-SSW, perpendicular to the SE direction assumed for the Tethyan slab retreat.

Some authors have suggested that the tectonic units forming the Calabride Complex originated either from the northern margin of the African plate (Bonardi et al., 2003) or from a microplate sandwiched between the African and the European plates (Cello et al., 1996; Liberi et al., 2006). However, on the basis of geometric reconstructions of the Mesozoic sedimentary sequences, meso- and microstructural observations, and palaeomagnetic measurements, the tectonic units forming the Calabride Complex are generally considered to have originated from the southern European margin (Bouillin, 1984; Dietricht, 1988; Bouillin et al., 1992; Gueguen et al., 1998; Faccenna et al., 2001; Rosenbaun et al., 2002; Rosenbaum and Lister, 2004). According to this model, plate kinematics resulted in the progressive closure of the Tethyan oceanic domain during the Eocene, accommodated by northwest-directed subduction underneath the southern European continental margin. The tectonic pile of the Calabrian-Peloritan belt was built up during this convergence and transported onto the African-Apulian palaeomargin.

In southern Calabria, a new geochronological study in the Aspromonte Massif provides new age constraints on the Alpine evolution of the Calabride Complex (Heymes et al., 2010). A SE stacking phase was probably initiated before $45 \mathrm{Ma}$ (Late Eocene), as suggested by K-feldspar ages from different structural levels in the Aspromonte Unit. The top-to-the-NE extensional reworking of the pile is dated at 28.6 Ma (Middle Oligocene), but new data indicate that the deepest units were partly exhumed after the Early Oligocene (36-33 Ma). This could suggest that the exhumation of southern Calabria was accommodated by several tectonic pulses from 45 to $28.6 \mathrm{Ma}$, with significant kinematic changes in this interval. In the Peloritan Mountains of Sicily, the tectonic evolution of the Calabride Complex is similar but both kinematic directions and ages for successive steps are poorly constrained (Somma et al., 2005).

4. An overall Plio-Quaternary thrust propagation was expressed by the formation of flexural foredeep systems. During the Pliocene, wedge thickening (OSC emplacement) and foreland bulging started again. Faults systems controlling the foreland-foredeep margin yet again suffered reactivation, allowing new accommodation space for the foredeep basin fills that were higher than in the thrust front region. Only shortening occurred in stage 1 (ISC and MSC p.p. emplacement, Oligocene-Middle Miocene). Active thrusting occurred only in the toe region and the thrust stack was passively carried. Thrust loading progressively and then created the conditions for incipient extension in the back of the wedge coeval to the compression in the thrust front (MSC full emplacement, Middle-Late Miocene, stage 2).

The arcuate shape of the Calabrian Arc, in particular, formed mostly between the Serravallian, after the end of the 


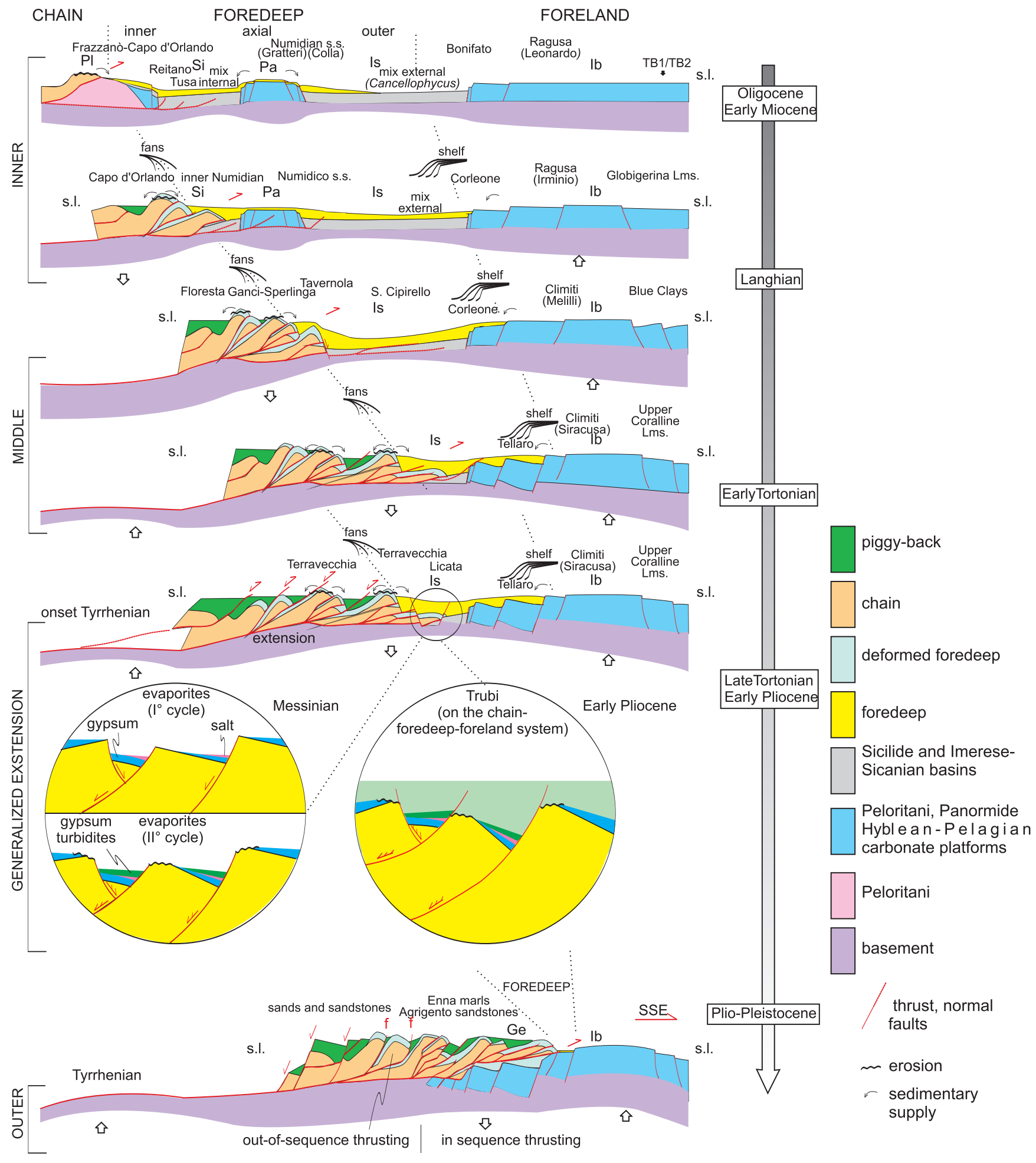

Fig. 12. Proposed tectonic model of the structural and sedimentary evolution of the Sicilian chain-foredeep-foreland system since the Oligocene, depicting the deformation of the pre- and syn-orogenic strata deposited in the different palaeogeographic domains and in the foredeep-foreland system

The ISC (Peloritani, Sicilide, Panormide and Imerese-Sicanian p.p.) and MSC (Imerese-Sicanian p.p.) were deformed from the Oligocene to the Late Miocene; an extensional setting developed during the Late Miocene-Early Pliocene, allowing the deposition of evaporites and deep-water marls (Trubi Fm.); these conditions allowed renewed deformation of the Imerese-Sicanian and previous foredeep deposits ("Gela Nappe" emplacement; modified after Nigro and Renda, 2000); Ge - "Gela Nappe", Ib - Hyblean-Pelagian, Is - Imerese-Sicanian, Pa - Panormide, Pl - Peloritani, Si - Sicilide 
Liguro-Provençal oceanic spreading phase (Faccenna et al., 2004, 2005; Cifelli et al., 2007; Mattei et al., 2007; Chiarabba et al., 2008) and the Late Miocene and the Pleistocene, during the opening of the Tyrrhenian Sea. Between 15 and $10 \mathrm{Ma}$, the retreat drastically decelerated (Faccenna et al., 2001). Assuming the outer wedge as a tectonic complex, in the evolution of the accretionary complex, most of the post-Messinian shortening can be accommodated by growth of the outer wedge and consequent underplating of the Meso-Cenozoic Ionian sedimentary sequence. Minelli and Faccenna's (2010) interpretation of seismic reflection profiles in the Ionian offshore sheds new light on the structure and evolution of the Calabrian accretionary wedge, a key area for the geodynamics of the Mediterranean compressive margin. These new data allow us to divide the evolution of the Calabrian accretionary wedge into two main phases: pre-Messinian and post-Messinian. The Messinian salinity crisis represents an important break in the evolution of the wedge, as the basal décollement ramps up onto the Messinian salt deposits, producing a dramatic and fast forward propagation of the frontal thrust and resulting underplating of the underlying crustal Ionian sequence during progressive trench rollback.

In stage 3, during Late Miocene-Early Pliocene, thrust break in the thrust front, and the negative inversion of the thrust in the ISC and MSC, took place. Starting from the Pliocene, the extensional rate in the back of the chain reduced to zero. In the outer STS, erosion during bowing-up of the isostatic adjustment encouraged renewed deformation in the toe (Gela Nappe). The Plio-Pleistocene thrusting is also expressed by out-of-sequence and breaching mechanisms in the STS, as well as in the southern Apennines (Patacca and Scandone, 1999).

Restart thrusting (stage 4) allowed for the in-sequence emplacement of the OSC, as well as for the out-of-sequence deformation in the ISC and MSC. Figure 13 depicts the map-view evolution of the Sicily Belt. As argued by Nigro and Renda (2001a, 2002), oblique slip thrusting closely constrained the present-day map-view wedge shape of the STS. Western Sicily suffered transpressional regimes related to the foreland fault indenter shape in turn related to the direction of the tectonic transport.

The Hyblean-Pelagian Block represents a variably thick (up to $5 \mathrm{~km}$; Bianchi et al., 1987) leading element of the African plate (Grasso et al., 1995; Moretti and Royden, 1998). The Hyblean-Pelagian Block is undetached from its continental crust in eastern Sicily and is bounded by inherited transfer structures (Reuther et al., 1993; Lickorish et al., 1999; Ragg et al., 1999). Its margins, controlled by Mesozoic faults, may have controlled the location of ramp bends during Oligocene-Pleistocene collisional, as discussed by Nigro and Renda (1999).

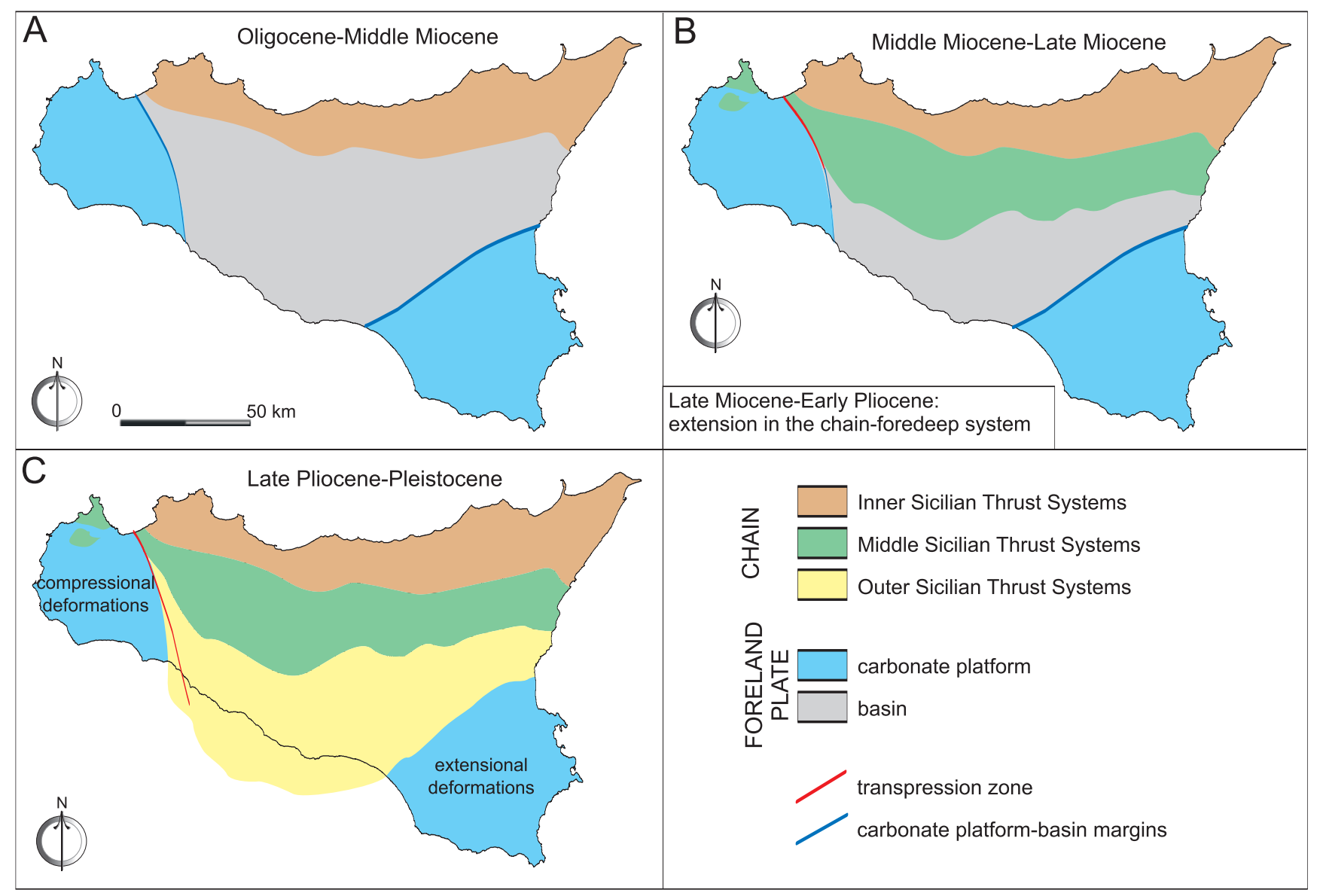

Fig. 13. Schematic map of the structural evolution of the STS 


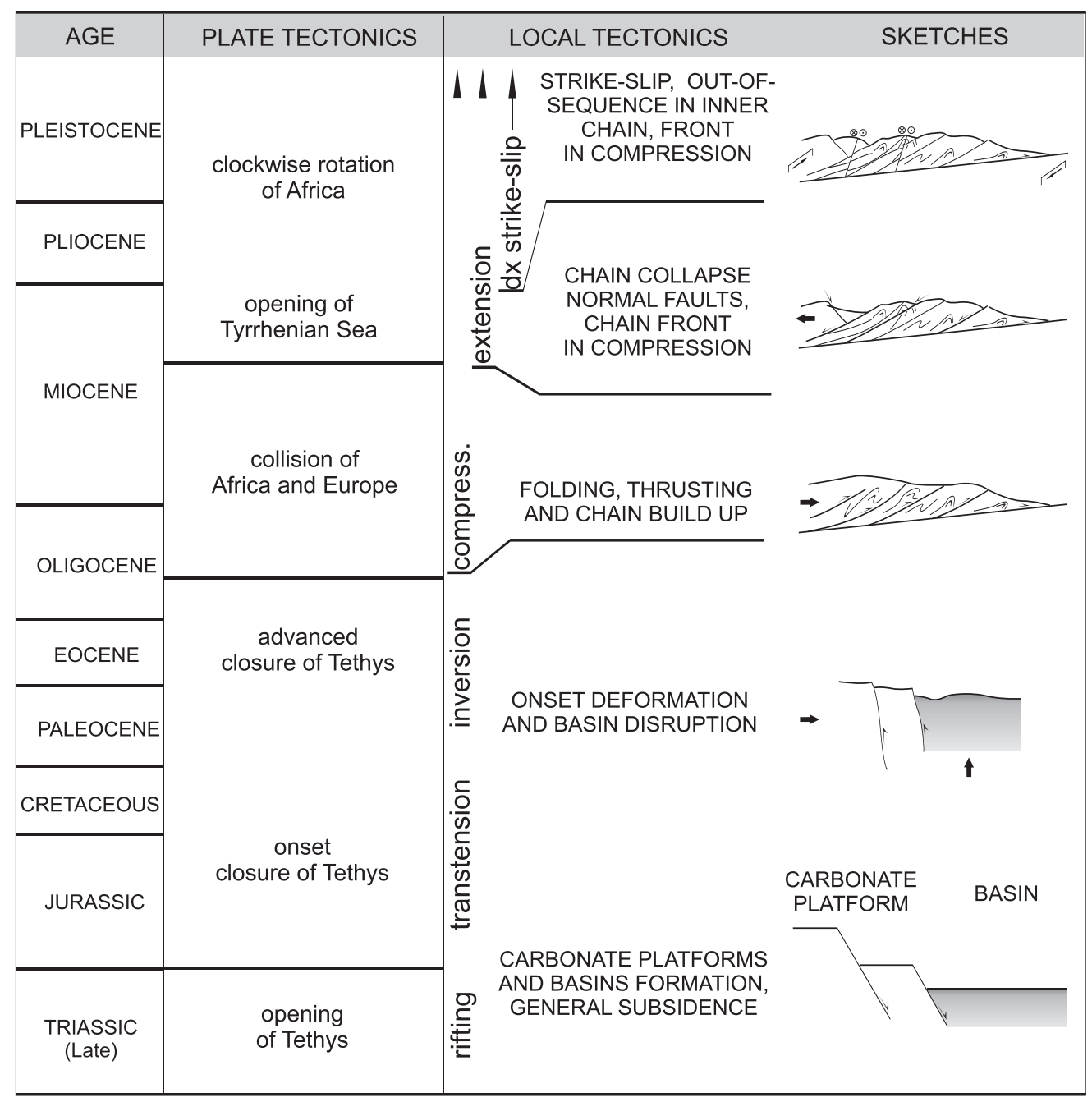

Fig. 14. Speculative, simplified scheme of timing of pre-, syn- and post-orogenic deformation episodes in the Sicilian sector of the Sicilian-Maghrebides orogenic belt (modified after Ślączka et al., 2012)

Rotation processes during the Miocene-Pliocene evolution of the STS were postulated by Channell et al. (1980), Nairn et al. (1985), Grasso et al. (1987a) and Oldow et al. (1990). Indeed, palaeomagnetic data indicate clockwise rotations progressively more developed towards the east of the different tectonic units, from about $30^{\circ}$ in the Trapani-S. Vito Mts. up to $90^{\circ}$ in the Peloritani Mts. The rotations within the STS since the Late Oligocene have generally been related to the rotation of the Sardinia-Corsica Block (Cherchi and Montadert, 1982), the counterclockwise Africa rotation (Dewey et al., 1989) and the "post-collisional" tectonics of the African continental margin (Boccaletti et al., 1990).

The control of the Hyblean-Pelagian Block over the structural trend-lines of the Sicily chain is inherent in its different deformation patterns in western and eastern Sicily (Lickorish et al., 1999), and in the arcuate geometry of the thrust front. The relationships between the amount of shortening produced during oblique convergence and the uneven shape of the foreland plate consist of deflecting trajectories near the foreland indenter template, whose margin acts as a regional oblique ramp during contractional tectonics, as predicted by the model of Macedo and Marshak (1999).
The curvature development may be related to the transport-parallel simple shear model of Ferrill (1991), in which a uniform displacement direction and an along-strike variation in the displacement magnitude and/or internal shortening cause simple shear parallel to the direction of transport. The simple shear parallel to the transport direction rotated and extended fold axes, initially nucleated perpendicular to transport. Rotation and associated strain resulting from the "differential displacement/differential shortening" may have been internally accommodated by small-scale fracturing and faulting, causing rotation of the map-scale marker lines.

Similar geometries characterize the western-central Sicily belt, where the smallest amount of thickening and shortening in its toe (so-called "Gela Nappe") is recognized in the arcuate thrust-front region (Nigro and Renda, 2002). The curvature of structural markers gradually converges farther away from the thrust front apex towards a NW-SE trending bend, where rotations of different magnitude are constrained by palaeomagnetic data.

The Hyblean-Pelagian Block underwent contractional tectonics diachronously from west to east (Nigro and Renda, 2002). In the west, its margin developed obliquely with respect 
to the orogenic front and was affected by transpression, producing reverse faulting and related folding from the Late Miocene. Eastwards, strike-parallelism induced Plio-Pleistocene supracrustal growth of the orogenic wedge ("Gela Nappe") and the bending of the Hyblean-Pelagian Block, which was affected by internal foreland-type extensional deformation. Figure 14 shows the tectonic evolution of Sicily from Tethys opening, chain building, until the Tyrrhenian opening.

\section{CONCLUSIONS}

Progressive structural evolution of the STS has been characterized by repeated fault reactivation (both positive and neg- ative inversion tectonics) and by mechanical accommodation of the different sectors related to thrust-sheet advance and then to the lithospheric applied loads.

Lithospheric flexure under static loads generated down-bending flexure proximal to the front of the orogenic belt, allowing the opening of a system of foredeep basins, which migrated as the load advanced forelandwards.

Acknowledgements. We would like to thank the referees of the journal, Z. Cymerman and M. Krobicki, for constructive reviews that improved this paper. Work was supported by MURST 60\% funds (P. Renda) and Istituto Nazionale di Geofisica e Vulcanologia, sez. di Palermo funds.

\section{REFERENCES}

ABATE B., CATAlano R., D’ARGENIO B., di STEFANO E., di STEFANO P., lo CICERO G., MONTANARI L., PECORARO C. and RENDA P. (1982) - Evoluzione delle zone di cerniera tra piattaforme carbonatiche e bacini nella Sicilia Occidentale. Mem. Soc. Geol. It., suppl. A, 24: 53-76.

ABATE B., INCANDELA A., RENDA P. and SLACZKA A. (1988) Depositional processes in a late Miocene, post tectonic basin (Terraveccia Fm, Scillato, Sicily). Ann. Soc. Geol. Pol., 69: 27-48.

ADAM J. (1996) - Kinematik und Dynamic des neogenen Falten- und Deckengurtels in Sizilien. Quantifizierung neotektonischer Deformationsprozesse in der zentralmediterranen Afro-Europäischen Konvergenzzone. PhD. Thesis, Herausgegeben von geowissenschaftlichen Instituten, Berlin.

ALVAREZ W., COCCOZZA T. and WEZEL F.C. (1974) - Fragmentation of the Alpine orogenic belt by microplate dispersal. Nature, 248: 309-314.

BEAUMONT C. (1981) - Foreland basins. Geoph. J. Royal Astr. Soc., 65: 291-329.

BELLO M., FRANCHINO A. and MERLINI S. (2000) - Structural model of Eastern Sicily. Mem. Soc. Geol. It., 55: 61-70.

BENEO E. (1958) - Sull'olistostroma quaternario di Gela (Sicilia meridionale). Boll. Serv. Geol. It., 79: 5-15.

BERNOULLI D. and JENKYNS H. (1974) - Alpine, Mediterranean and central Atlantic Mesozoic facies in relation to the early evolution of the Tethys. SEPM Spec. Publ., 19: 129-160.

BIANCHI F., CARBONE S., GRASSO M., INVERNIZZI G., LENTINI F., LONGARETTI G., MERLINI S. and MOSTARDINI F. (1987) Sicilia orientale: profilo geologico Nebrodi-Iblei. Mem. Soc. Geol. It., 38: 429-458.

BIJU-DUVAL B., DERCOURT J. and Le PICHON X. (1977) - From the Tethys ocean to the Mediterranean seas: a plate tectonic model of the evolution of the Western Alpine System. In: Structural History of the Mediterranean Basins (eds. B. Biju-Duval and L. Montadert): 143-164. Proc. Int. Symp., Ed. Technip, Paris.

BOCCALETTI M., CONEDERA C., DAINELLI P. and GOCEV P. (1982) - The recent (Miocene-Quaternary) rhegmatic system of western Mediterranean region. A new model of ensialic geodynamic evolution in a context of plastic/rigid deformation. J. Petrol. Geol., 5: 31-49.

BOCCALETTI M., CIARANFI N., COSENTINO D., DEIANA G., GELATI R., LENTINI F., MASSARI F., MORATTI G., PESCATORE T.S., RICCI LUCCHI F. and TORTORICI L. (1990) - Palinspastic restoration and paleogeographic reconstruction of the peri-Tyrrhenian area during the Neogene. Palaeogeogr. Palaeoclimatol. Palaeoecol., 77: $41-50$.
BONARDI G., CAVAZZA W., PERRONE V. and ROSSI S. (2001) Calabria-Peloritani terrane and northern Ionian Sea. In: Anatomy of an Orogen: the Apennines and Adjacent Mediterranean Basins (eds. G.B. Vai and I.P. Martini): 287-306. Kluwer Acad. Publ., Dordrecht.

BONARDI G., de CAPOA P., di STASO A., ESTEVEZ A., MARTIN-MARTIN M., MARTIN-ROJAS I., PERRONE V. and TENT-MANCLUS J.E. (2003) - Oligocene-to-Early-Miocene depositional and structural evolution of the Calabria-Peloritani Arc southern terrane (Italy) and geodynamic correlations with the Spains Betics and Morocco Rif. Geodinam. Acta, 16: 149-169.

BOUILLIN J.P. (1984) - Nouvelle interprétation de la liaison Apennin-Maghrébides en Calabre; conséquences sur la paléogéographie téthysienne entre Gibraltar et les Alpes. Rev. Géol. Dyn. Géogr. Phys., 25 (5): 321-338.

BOUILLIN J.P., DUMONT T. and OLIVIER P. (1992) - Organisation structurale et sédimentaire de la paléomarge nord téthysienne au Jurassique dans les monts Péloritains (Sicile, Italie). Bull. Soc. Géol. France, 163 (6): 761-770.

BROQUET P., CAIRE A. and MASCLE G. (1966) - Structure et évolution de la Sicile occidentale (Madonie et Sicani). Bull. Soc. Géol. France, sér. 7, 8: 994-1013.

BROQUET P., DUEE G., MASCLE G. and TRUILLET R. (1984) - Evolution structurale alpine récente de la Sicile et sa signification géodynamique. Rev. Géol. Dyn. Géogr. Phys., 25 (2): 75-85.

CARMIGNANI L., DECANDIA F.A., FANTOZZI P.L., LAZZAROTTO A., LIOTTA D. and MECCHERI M. (1994) - Tertiary extensional tectonics in Tuscany (Northern Apennines, Italy). Tectonophysics, 238: 295-315.

CARRARA A. and ZUFFA G.G. (1976) - Alpine structures in northwestern Calabria, Italy. GSA Bull., 87: 1229-1246.

CATALANO R. and D'ARGENIO B. (1982) - Schema geologico della Sicilia. Guide Geologiche Regionali. Mem. Soc. Geol. It., suppl. A, 4: $9-41$.

CATALANO R., CHANNELL J.E.T., D'ARGENIO B. and NAPOLEONE G. (1977)-Mesozoic palaeogeography of the southern Apennines and Sicily. Mem. Soc. Geol. It., 15: 95-118.

CATALANO R., di STEFANO E., lo CICERO G., di STEFANO P. and AGNESI V. (1979) - Contributo alla conoscenza della struttura della Sicilia Occidentale: il profilo Palermo-Sciacca. Boll. Soc. Geol. It., 19: 485-493.

CATALANO R., FRANCHINO A., GIUNTA G., MERLINI S. and SULLI A. (1998) - Ipotesi sulla prosecuzione settentrionale delle Unitŕ Sicanenell'area di Rocca Busambra. Field trip guide book of 79th Congr. Naz. SGI: 268-271. 
CATALANO R., FRANCHINO A., MERLINI S. and SULLI A. (2000) Central western Sicily structural setting interpreted from seismic reflection profiles. Mem. Soc. Geol. It., 55: 5-16.

CELLO G., INVERNIZZI C. and MAZZOLI S. (1996) - Structural signature of tectonic processes in the Calabrian arc, southern Italy. Evidence from the oceanic-derived Diamante-Terranova unit. Tectonics, 15: $187-200$

CHANNELL J.E.T., CATALANO R. and D'ARGENIO B. (1980) Paleomagnetism and deformation of the Mesozoic continental margin in Sicily. Tectonophysics, 58: 391-407.

CHAPPLE W.M. (1978) - Mechanics of thin-skinned fold-and-thrust belts. GSA Bull., 89: 1189-1198.

CHERCHI A. and MONTADERT L. (1982) - Oligo-Miocene rift of Sardinia and the early history of the Western Mediterranean basin. Nature, 298: 736-739.

CHIARABBA C., de GORI P. and SPERANZA F. (2008) - The southern Tyrrhenian subduction zone: deep geometry, magmatism and Plio-Pleistocene evolution. Earth Planet. Sc. Lett., 268: 408-423.

CIFELLI F., MATTEI M. and ROSSETTIF. (2007) - Tectonic evolution of arcuate mountain belts on top of a retreating subduction slab: the example of the Calabrian Arc. J. Geophys. Res., 112: B09101.

CIRRINCIONE R. and PEZZINO A. (1994) - Nuovi dati struturali sulle successioni mesozoiche metamorfiche dei Monti Peloritani orientali. Boll. Soc. Geol. It., 113: 195-203.

DAVIS D., SUPPE J. and DAHLEN F.A. (1983) - Mechanics of fold-and-thrust belts and accretionary wedges. J. Geophys. Res., 88: 1153-1172.

De GREGORIO S., ROTOLO S.G. and VILLA I.M. (2003) - Geochronology of the medium to high grade metamorphic units of the Peloritani Mts., Sicily. Int. J. Earth Sc., 92: 852-872.

DEWEY J.F. (1988) - Extensional collapse of orogens. Tectonics, 7: 1123-1139.

DEWEY J.F., HELMAN M.L., TURCO E., HUTTON D.H.W. and KNOTT S.D. (1989) - Kinematics of the Western Mediterranean. Geol. Soc., Spec. Publ., 45: 265-283.

Di STEFANO P., ANDREINI G., BARTOLINI A., BALDANZA A., BERTOK C., BUCEFALO PALLIANI R., CARACUEL J., CENSI P., CHIARI M., COPE J.C.W., D’ARPA C., FERLA P., GALACZ A., GULLO M., LOZAR F., MALLARINO G., MARINO M.C., MARINO M., MURARO M., MARIOTTI N., MARTIRE L., MATTIOLI E., MELENDEZ G., MELI C., MINDSZENTY A., MONTAGNINO D., NICOSIA U., NICCHITTA D., PALLINI G., PARISI G., PAVIA G., PETTI F.M., SANTANTONIO M., SARTI C., SPEZIALE S. and VÖRÖS A. (2002) - An introduction to the Jurassic Geology of western Sicily. In: General Field Trip Guidebook (ed. M. Santantonio). VI International Symposium on the Jurassic System, 12-22 September 2002, Palermo, Italy.

DIETRICHT D. (1988) - Sense of overthrust shear in the Alpine nappes of Calabria (Southern Italy). J. Struct. Geol., 10 (4): 373-381.

ENGLAND P.C. and McKENZIE D.P. (1982) - A thin viscous sheet model for continental deformation. Geophys. J. R. Astron. Soc., 70: 295-321.

FACCENNA C., BECKER T.W., LUCENTE F.P., JOLIVET L. and ROSSETTI F. (2001) - History of subduction and back-arc extension in the Central Mediterranean. Geophys. Lett., 145: 809-820.

FACCENNA C., PIROMALLO C., CRESPO-BLANC A., JOLIVET L. and ROSSETTI F. (2004) - Lateral slab deformation and the origin of the Western Mediterranean arcs. Tectonics, 23: TC1012, doi: 10.1029/2002TC001488

FACCENNA C., CIVETTA L., D’ANTONIO M., FUNICIELlO F., MARGHERITI L. and PIROMALLO C. (2005) - Constraints on mantle circulation around the deforming Calabrian slab. Geophys. Res. Lett., 32: L06311.

FERRILL D.A. (1991) - Curvature development and limestone deformation in the Northern Subalpine Chain (Haute-Savoie, France). Ph.D. Thesis, University of Alabama.

FINETTI I. and del BEN A. (1986) - Geophysical study of the Tyrrhenian opening. Boll. Geof. Teor. Appl., 28: 75-155.

FINETTI I., LENTINI F., CARBONE S., CATALANO S. and del BEN A. (1996) - Il sistema Appennino meridionale-Arco Calabro-Sicilia nel Mediterraneo Centrale: studio geologico-geofisico. Boll. Soc. Geol. It., 115: 529-559.
FLORES G. (1959) - Evidence of slump phenomena (olistostromes) in areas of hydrocarbon exploration in Sicily. Proceedings 5th World Petroleum Congress, Roma, Sect. 1, 13: 259-275.

FREPOLI A. and AMATO A. (2000) - Spatial variation in stresses in peninsular Italy and Sicily from background seismicity. Tectonophysics, 317: 109-124.

GHISETTI F. and VEZZANI L. (1984) - Thin-skinned deformation in Western Sicily. Boll. Soc. Geol. It., 103: 129-157.

GIUNTA G. (1985) - Problematiche ed ipotesi sul bacino numidico nelle Maghrebidi siciliane. Boll. Soc. Geol. It., 104: 239-256.

GIUNTA G. (1991) - Elementi per un modello cinematico delle maghrebidi siciliane. Mem. Soc. Geol. It., 47: 297-311.

GIUNTA G. and NIGRO F. (1999) - Some tectono-sedimentary constraints to Oligo-Miocene evolution of the Peloritani Thrust Belt. Tectonophysics, 315: 287-299.

GIUNTA G., NIGRO F. and RENDA P. (2000) - Extensional tectonics during Maghrebides chain building since late Miocene: examples from Northern Sicily. Ann. Soc. Geol. Pol., 70: 81-98.

GIUNTA G., NIGRO F. and RENDA P. (2002) - Inverted structures in Western Sicily. Boll. Soc. Geol. It., 121: 11-17.

GRANDE A., di VINCENZO G., PROSSER G. and CAGGIANELLI A. (2009) - Direct evidence of Middle Oligocene extension in the Calabria-Peloritani terrane from co-seismic faulting: the pseudotachylyte-bearing shear zones of Palmi (southern Calabria, Italy). Terra Nova, 21: 293-303.

GRANDJACQUET C. and MASCLE G. (1978) - The structures of the Ionian sea, Sicily and Calabria-Lucania. In: The Western Mediterranean (eds. A.E.M. Nairn, W.H. Kanes and F.G. Stehli): 257-329. Plenum Press, New York, 4B.

GRASSO M., MANZONI M. and QUINTILI A. (1987) - Misure magnetiche sui Trubi infrapliocenici della Sicilia Orientale: possibili implicazioni stratigrafiche e strutturali. Mem. Soc. Geol. It., 38: 459-474.

GRASSO M., MIUCCIO G., MANISCALCO R., GAROFALO P., la MANNA F. and STAMILIA R. (1995) - Plio-Pleistocene structural evolution of the western margin of the Hyblean Plateau and the Maghrebian foredeep, SE Sicily. Implications for the deformational history of the Gela Nappe. Ann. Tecton., 9 (1-2): 7-21.

GUEGUEN E., DOGLIONI C. and FERNANDEZ M. (1998) - On the post-25 Ma geodynamic evolution of the western Mediterranean. Tectonophysics, 298 (1-3): 259-269.

HAQ B.U., HARDENBOL J., VAIL P.R., STOVER L.E., COLIN J.P., IOANNIDES N.S., WRIGHT R.C., BAUM G.R., GOMBOS A.M., PFLUM C.E., LUOTIT T.S., JAN du CHENE R., ROMINE K.K., SARG J.F., POSAMENTIER H.W. and MORGAN B.E. (1988) - Mesozoic and Cenozoic chronostratigraphy and cycles of sea-level change. SEPM Spec. Publ., 42: 71-108.

HEYMES T., BOUILLIN J.P., PECCHER A., MONIÉ P. and COMPAGNONI R. (2008) - Middle Oligocene extension in the Mediterranean Calabro-Peloritan belt (southern Italy): insights from the Aspromonte nappes pile. Tectonics, 27: TC2006, doi:10.1029/2007TC002157

HEYMES T., MONIÉ P., ARNAUD N., PĘCHER A., BOUILLIN J.P. and COMPAGNONI R. (2010) - Alpine tectonics in the Calabrian-Peloritan belt (southern Italy): new ${ }^{40} \mathrm{Ar} /{ }^{39} \mathrm{Ar}$ data in the Aspromonte Massif area. Lithos, 114: 451-472.

IANNACE A., VITALE S., D'ERRICO M., MAZZOLI S., di STASO A., MACAIONE E., MESSINA A., REDDY S.M., SOMMA R., ZAMPARELLI V., ZATTIN M. and BONARDI G. (2007) - The carbonate tectonic units of northern Calabria (Italy): a record of Apulian paleomargin evolution and Miocene convergence, continental crust subduction, and exhumation of HP-LT rocks. J. Geol. Soc., 164: 1165-1186.

JACKSON J. and McKENZIE D. (1988) - The relationship between plate motions and seismic tremors, and the rates of active deformation in the Mediterranean and Middle East. Geophys. J. R. Astron. Soc., 93: 45-73.

JIMÉNEZ-MUNT I., SABADINI R., GARDI A. and BIANCO G. (2003) The block-like behavior of Anatolia envisaged in the modeled and geodetic strain rates. J. Geophys. Res., 108 (B1): doi: 10.1029/2001-JB001544 
JOLIVET L. and FACCENNA C. (2000) - Mediterranean extension and the Africa-Eurasia collision. Tectonics, 19: 1095-1106.

JOLIVET L., FACCENNA C., GOFFÉ B., BUROV E. and AGARD P. (2003) - Subduction tectonics and exhumation of high-pressure metamorphic rocks in the Mediterranean orogens. Am. J. Sc., 303: 353-409.

KELLER J.V.A., MINELLI G. and PIALLI G. (1994) - Anatomy of late orogenic extension: the Northern Apennines case. Tectonophysics, 238: $275-294$

KEZIRIAN F., BARRIER P., BOUILLIN J.P. and JANIN M.C. (1994) The Peloritan Oligo-Miocene (Sicily) - a remnant of the Algero-Provençal Basin Rifting. C. R. Acad. Sc. Paris, ser. II, 319 (2): 699-704.

KNOTT S.D. (1994) - Structure, kinematics and metamorphism in the Liguride Complex, southern Apennines, Italy. J. Struct. Geol., 16 (8): 1107-1120.

LAVECCHIA G., FERRARIN F., de NARDIS I.R., VISINI F. and BARBANO M.S. (2007) - Active thrusting as a possible seismogenic source in Sicily (Southern Italy): some insights from integrated structural-kinematic and seismological data. Tectonophysics, 445: 145-167.

LIBERI F., MORTEN L. and PILUSO E. (2006) - Geodynamic significance of ophiolites within the Calabrian Arc. Island Arc, 15: 26-43.

LICKORISH W.H., GRASSO M., BUTLER R.W.H., ARGNANI A. and MANISCALCO R. (1999) - Structural styles and regional tectonic setting of the "Gela Nappe" and frontal part of the Maghrebian thrust belt in Sicily. Tectonics, 18 (4): 669-685.

MACEDO J. and MARSHAK S. (1999) - Controls on the geometry of fold-thrust salients. GSA Bull., 111 (12): 1808-1822.

MANTOVANI E., ALBARELLO D., TAMBURELLI C., BABBUCCI D. and VITI M. (1997) - Plate convergence, crustal delamination, extrusion tectonics and minimization of shortening work as main controlling factors of the recent Mediterranean deformation pattern. Ann. Geophys., 40: 611-643.

MASCLE G. (1970) - Geological sketch of western Sicily. Reprinted from "Geology and history of Sicily" (eds. W. Alvarez and K.H.A. Gohrbandt). Petrol. Expl. Soc. Lib.

MASCLE G. (1979) - Etude géologique des Monts Sicani. Riv. It. Pal. Strat., Mem., 16.

MATTEI M., CIFELLI F. and D'AGOSTINO N. (2007) - The evolution of the Calabrian Arc: evidence from paleomagnetic and GPS observations. Earth Planet. Sc. Lett., 263 (3-4): 259-274.

MCKENZIE D.P. (1970) - Plate tectonics of the Mediterranean region. Nature, 226: 239- 243.

MINELLI L. and FACCENNA C. (2010) - Evolution of the Calabrian accretionary wedge (central Mediterranean). Tectonics, 29: TC4004, doi: $10.1029 / 2009$ TC002562

MORETTI I. and ROYDEN L. (1998) - Deflexion, gravity anomalies and tectonics of doubly subducted lithosphere: Adriatic and Ionian seas. Tectonics, 7: 875-896.

MORLEY C.K. (1988) - Out of Sequence Thrusts. Tectonics, 7: 539-561.

MUELLER B., REINECKER J., HEIDBACH O. and FUCHS K. (2000) The 2000 release of the World Stress Map. (Available at www.world-stress-map.org)

NAIRN A.E.M., NARDI G., GREGOR C.B. and INCORONATO A. (1985) - Coherence of the Trapanese units during tectonic emplacement in Western Sicily. Boll. Soc. Geol. It., 104: 267-272.

NIGRO F. and RENDA P. (1999) - Evoluzione geologica ed assetto strutturale della Sicilia centro-settentrionale. Boll. Soc. Geol. It., 118: $375-388$.

NIGRO F. and RENDA P. (2000) - Un modello di evoluzione tettono-sedimentaria dell' avanfossa neogenica siciliana. Boll. Soc. Geol. It., 119: 667-686.

NIGRO F. and RENDA P. (2001a) - Oblique-slip thrusting in the Maghrebide chain of Sicily. Boll. Soc. Geol. It., 120: 187-200.

NIGRO F. and RENDA P. (2001b) - Late Miocene-Quaternary stratigraphic record in the Sicilian Belt (Central Mediterranean): tectonics versus eustasy. Boll. Soc. Geol. It., 120: 151-164.

NIGRO F. and RENDA P. (2002) - Forced mode dictated by foreland fault-indenter during oblique convergence: the Western Sicily mainland. Boll. Soc. Geol. It., 121: 151-162.
NIGRO F. and RENDA P. (2004a) - The contribution of pre-existing structures in mountain belt evolution: the example of the negative inversion in Northern Sicily. Boll. Soc. Geol. It., 123: 175-187.

NIGRO F. and RENDA P. (2004b) - Sequence of deformations in the Sicilidi Units (Northern Sicilian chain). Boll. Soc. Geol. It., 123: 97-110.

NIGRO F. and RENDA P. (2005) - Transtensional/extensional fault activity from the Mesozoic rifting chain building in Northern Sicily (Central Mediterranean). Geol. Carpath., 56: 255-271.

OGNIBEN L. (1960) - Nota illustrativa dello schema geologico della Sicilia nord-orientale. Riv. Min. Sic., 64-65: 184-212.

OGNIBEN L. (1973) - Schema geologico della Calabria in base ai dati odierni. Geol. Romana, 12: 243-585.

OLDOW J.S., CHANNELL J.E.T., CATALANO R. and D'ARGENIO B. (1990) - Contemporaneous thrusting and large-scale rotations in the Western Sicilian fold and thrust belt. Tectonics, 9: 661-681.

OLDOW J.S., D'ARGENIO B., FERRANTI L., PAPPONE G., MARSELLA E. and SACCHI M. (1993) - Large-scale longitudinal extension in the Southern Apennines contractional belt, Italy. Geology, 21: 1123-1126.

PATACCA E. and SCANDONE P. (1999) - Late thrust propagation and sedimentary response in the thrust belt foredeep system of the Southern Appennines (Pliocene-Pleistocene). In: Anatomy of Mountain: the Appennines and Adjacent Mediterranean Basins (eds. G.B. Vai and I.P. Martini): 1-47. Chapman and Hall.

PEDLEY H.M. and GRASSO M. (1992) - Miocene syntectonic sedimentation along the western margins of the Hyblean-Malta platform: a guide to plate margin processes in the central Mediterranean. J. Geodynamics, 15 (1/2): 19-37.

PESCATORE T., RENDA P. and TRAMUTOLI M. (1987) - Facies ed evoluzione sedimentaria del Bacino Numidico nelle Madonie Occidentali (Sicilia). Mem. Soc. Geol. It., 38: 297-316.

PLATT J.P. (1986) - Dynamics of orogenic wedges and the uplift of high-pressure metamorphic rocks. GSA Bull., 97: 1037-1053.

PLATT J.P. (2007) - From orogenic hinterlands to Mediterranean-style back-arc basins: a comparative analysis. J. Geol. Soc., 164: 297-311.

PLATT J.P. and COMPAGNONI R. (1990) - Alpine ductile deformation and metamorphism in a Calabrian basement nappe (Aspromonte, South Italy). Ecl. Geol. Helv., 83 (1): 41-58.

PLATT J.P. and VISSERS R.L.M. (1989) - Extensional collapse of thickened continental lithosphere: a working hypothesis for the Alboran Sea and Gibraltar arc. Geology, 17: 540-543.

RAGG S., GRASSO M. and MULLER B. (1999) - Patterns of tectonic stress in Sicily from borehole breakout observations and finite element modelling. Tectonics, 18: 669-685.

REBAI S., PHILIP H. and TABOADA A. (1992) - Modern tectonics stress field in the Mediterranean region: evidence for variation in stress directions at different scales. Geophys. J. Int., 110: 106-140.

REUTHER C.D., BEN-AVRAHAM Z. and GRASSO M. (1993) - Origin and role of major strike-slip transfers during plate collision in the central Mediterranean. Terra Nova, 5: 249-257.

ROLLET N., DEVERCHČRE J., BESLIER M.O., GUENNOC P., REHAULT J.P., SOSSON M. and TRUFFERT C. (2002) - Back arc extension, tectonic inheritance, and volcanism in the Ligurian Sea, Western Mediterranean. Tectonics, 21 (3): TC900027, doi: 10.1029/2-001TC900027

ROSSETTI F., FACCENNA C., GOFFČ B., MONIČ P., ARGENTIERI A., FUNICIELLO R. and MATTEI M. (2001) - Alpine structural and metamorphism signature of the Sila Piccola Massif nappe stack (Calabria, Italy): insights for the tectonic evolution of the Calabrian Arc. Tectonics, 20: 114-133.

ROSSETTI F., GOFFÉ B., MONIÉ P., FACCENNA C. and VIGNAROLI G. (2004) - Alpine orogenic P-T-deformation history of the Catena Costiera area and surrounding regions (Calabria Arc, southern Italy): the nappe edifice of north Calabria revised with insights on the Tyrrhenian-Apennine system formation. Tectonics, 23: TC6011, doi: 10.1029/2003TC001560

ROSENBAUM G. and LISTER G.S. (2004) - Neogene and Quaternary rollback evolution of the Tyrrhenian Sea, the Apennines, and the Sicilian Maghrebides. Tectonics, 23, TC1013, doi: 10.1029/2003-TC001518 
ROSENBAUM G., LISTER G.S. and DUBOZ C. (2002) - Relative motions of Africa, Iberia and Europe during Alpine orogeny. Tectonophysics, 359 (1-2): 117-129.

ROURE F., HOWELL D.G., GUELLEC S. and CASERO P. (1990a) Shallow structures induced by deep-seated thrusting. In: Petroleum and Tectonics in Mobile Belts (ed. J. Letouzey). Technip, Paris, 43: $15-30$.

ROURE F., HOWELL D.G., MULLER C. and MORETTI I. (1990b) Late Cenozoic subduction complex of Sicily. J. Struct. Geol., 12 (2): 259-266.

SCANDONE P., GIUNTA G. and LIGUORI V. (1974) - The connection between Apulia and Sahara continental margins in the Southern Apennines and in Sicily. Mem. Soc. Geol. It., 13: 317-323.

SCISCIANNI V., CALAMITA F., TAVARNELLI E., RUSCIADELLI G., ORI G.G. and PALTRINIERI W. (2001) - Foreland-dipping normal faults in the inner edges of syn-orogenic basins: a case from the Central Apennines, Italy. Tectonophysics, 330: 211-224.

SCISCIANNI V., TAVARNELLI E. and CALAMITA F. (2002) - The interaction of extensional and contractional deformation in the outer zones of the Central Apennines, Italy. J. Struct. Geol., 24: 1647-1658.

SINCLAIR H.D. and ALLEN P.A. (1992) - Vertical versus horizontal motions in the Alpine orogenic wedge: stratigraphic response in the foreland basin. Basin Res., 4: 215-232.

SMIT J.H.W., BRUN J.P. and SOKOUTIS D. (2003) - Deformation of brittle-ductile thrust wedges in experiments and nature. J. Geophys. Res., 108: 2480.

SOMMA R., MESSINA A. and MAZZOLI S. (2005) - Syn-orogenic extension in the Peloritani, Alpine Thrust Belt (NE Sicily, Italy): evidence from the Alě Unit. C.-R. Geosc., 337: 861-871.

ŚLĄCZKA A., RENDA P., CIESZKOWSKI M., GOLONKA J. and NIGRO F. (2012) - Sedimentary basins evolution and olistoliths formation: the case of Carpathian and Sicilian regions. Tectonophysics, (568-569): 306-319, doi: 10.1016/j.tecto.2012.03.018

TAVARNELLI E., RENDA P., PASQUI V. and TRAMUTOLI M. (2003) The effects of post-orogenic estension on different scales: an examples from the Apennine-Maghrebides fold-and- thrust belt, NW Sicily. Terra Nova, 15: 1-7.
THOMSON S.N. (1994) - Fission track analysis of the crystalline basement rocks of the Calabrian arc, southern Italy: evidence of Oligo-Miocene late-orogenic extension and erosion. Tectonophysics, 238 (1-4): 331-352.

THOMSON S.N. (1998) - Assessing the nature of tectonic contacts using fission-track thermochronology: an example from the Calabrian Arc, southern Italy. Terra Nova, 10 (1): 32-36.

TRICART P., TORELLI L., ARGNANI A., REKHISS F. and ZITELLINI N. (1994) - Extensional collapse related to compressional uplift in the Alpine Chain of northern Tunisia (Central Mediterranean). Tectonophysics, 238: 317-329.

TRUILLET R. (1966) - Existence de filons sédimentaires homogPnes et granoclassés dans les environs de Taormina (monts Péloritains-Sicile). C. R. Som. Soc. Géol. France, 9: 354-359.

VIGLIOTTI L. and LANGENHEIM V.E. (1995) - When did Sardinia stop rotating - new paleomagnetic results. Terra Nova, 7 (4): 424-435.

VITALE F.P. (1990) - Studi sulla Valle del Belice (Sicilia centrooccidentale). L'avanfossa plio-pleistocenica nel quadro dell'evoluzione paleotettonica dell'area. Ph.D. Thesis, Palermo.

WALLIS S.R., PLATT J.P. and KNOTT S.D. (1993) - Recognition of syn-convergence extension in accretionary wedges with examples from the Calabrian Arc and the Eastern Alps. Am. J. Sc., 293: 463-495.

WENDT J. (1965) - Synsedimentäre Bruchtektonik im Jura Westsiziliens. N. Jb. Geol. Paläont. Mh., (5): 286-311.

WESTPHAL M., ORSINI J. and VELLUTINI P. (1976) - Corsica-Sardinia microcontinent, its initial position - paleomagnetic data and geological fitting. Tectonophysics, 30 (1-2): 141-157.

WILLETT S.D. (1992) - Dynamic and kinematic growth and change of a Coulomb wedge. In: Thrust Tectonics (ed. K.R. McClay): 19-31. Chapman and Hall, London.

WILLETT S.D. and BRANDON M.T. (2002) - On steady states in mountain belts. Geology, 30: 175-178.

WILLIAMS G.D., POWELL C.M. and COOPER M.A. (1989) - Geometry and kinematics of inversion tectonics. Geol. Soc. Spec. Publ., 44: $3-15$. 